\title{
Combustion characteristics of compression ignition engine fuelled with rapeseed oil-diesel fuel-n-butanol blends
}

\author{
Jakub Čedík ${ }^{1}$, Martin Pexa ${ }^{1, *}$, Bohuslav Peterka $^{1}$, Miroslav Müller ${ }^{2}$, Michal Holubek ${ }^{1}$, \\ Sergej $\mathrm{Hloch}^{3}$, and Marian Kučera ${ }^{4}$ \\ ${ }^{1}$ Department for Quality and Dependability of Machines Czech University of Life Sciences Prague, Faculty of Engineering, \\ Kamýcká 129, 16521 Prague 6, Czech Republic \\ ${ }^{2}$ Department of Material Science and Manufacturing Technology Czech University of Life Sciences Prague, Faculty of Engineering, \\ Kamýcká 129, 16521 Prague 6, Czech Republic \\ ${ }^{3}$ Faculty of Manufacturing Technologies TUKE with a seat in Prešov, Bayerova 1, 08001 Prešov, Slovakia \\ ${ }^{4}$ Faculty of Technology, Technical University in Zvolen, Študentská 26, 96001 Zvolen, Slovakia
}

Received: 29 May 2020 / Accepted: 4 January 2021

\begin{abstract}
Liquid biofuels for compression ignition engines are often based on vegetable oils. In order to be used in compression ignition engine the vegetable oils have to be processed because of their high viscosity or it is also possible to use vegetable oils in fuel blends. In order to decrease the viscosity of the fuel blends containing crude vegetable oil the alcohol-based fuel admixtures can be used. The paper describes the effect of rapeseed oil-diesel fuel-n-butanol blends on combustion characteristics and solid particles production of turbocharged compression ignition engine. The $10 \%$ and $20 \%$ concentrations of n-butanol in the fuel blend were measured and analysed. The engine Zetor 1204, located in tractor Zetor Forterra 8641 with the power of $60 \mathrm{~kW}$ and direct injection was used for the measurement. The engine was loaded through power take off shaft of the tractor using mobile dynamometer MAHA ZW500. The measurement was carried out in stabilized conditions at $20 \%, 60 \%$ and $100 \%$ engine load. The engine speed was kept at $1950 \mathrm{rpm}$. Tested fuel blends showed lower production of solid particles than diesel fuel and lower peak cylinder pressure and with increasing concentration of n-butanol in the fuel blend the ignition delay was prolonged and premixed phase of combustion was increased.
\end{abstract}

\section{Nomenclature}

$\mathrm{d} Q / \mathrm{d} \theta \quad$ Heat release rate $\left(\mathrm{J} /{ }^{\circ} \mathrm{CA}\right)$

$V \quad$ Instantaneous cylinder volume $\left(\mathrm{m}^{3}\right)$

$p \quad$ Cylinder pressure $(\mathrm{Pa})$

$\theta \quad$ Crankshaft angle $\left({ }^{\circ} \mathrm{CA}\right)$

$\gamma$

Ratio of specific heats at constant pressure and volume (according to [1] and [2] considered constant at 1.35)

$Q_{\mathrm{CHR}}$

$\mathrm{SOC}$

EOC

$W_{i}$

$T$

$m$

$R_{i}$ Cumulative Heat Release $(\mathrm{J})$

Start Of Combustion $\left({ }^{\circ} \mathrm{CA}\right)$

End Of Combustion $\left({ }^{\circ} \mathrm{CA}\right)$

Indicated work ( $\mathrm{J}$ cycle $\left.{ }^{-1}\right)$

Temperature of charge in the cylinder $(\mathrm{K})$

Mass air flow per cycle $(\mathrm{kg})$

Specific gas constant of air $\left(\mathrm{J} \mathrm{kg}^{-1} \mathrm{~K}^{-1}\right)$

$\begin{array}{ll}\text { Acronyms } & \\ \alpha & \text { Significance level } \\ \text { ANOVA } & \text { Analysis Of Variance } \\ \text { BSFC } & \text { Brake Specific Fuel Consumption } \\ \text { BTDC } & \text { Before Top Dead Center } \\ \text { BTE } & \text { Brake Thermal Efficiency } \\ \text { CA } & \text { Crankshaft Angle } \\ \text { CD } & \text { Combustion Duration } \\ \text { CI } & \text { Confidence Interval } \\ \text { D100 } & \text { Diesel fuel } \\ \text { EEPS } & \text { Engine Exhaust Particle Sizer } \\ \text { EOC } & \text { End Of Combustion } \\ \text { GHG } & \text { GreenHouse Gases } \\ \text { HRR } & \text { Heat Release Rate } \\ \text { HSD } & \text { Honestly Significant Difference } \\ \text { ID } & \text { Ignition Delay } \\ \text { IE } & \text { Indicated Efficiency } \\ m & \text { Mass air flow per cycle }\end{array}$

* Corresponding author: pexa@tf.czu.cz 


$\begin{array}{ll}\text { NOX } & \text { Nitrogen OXides } \\ p & \text { Cylinder pressure } \\ \text { PM } & \text { Particulate Matter } \\ \text { PTO } & \text { Power Take Off } \\ Q & \text { Heat } \\ Q_{\text {CHR }} & \text { Cumulative Heat Release } \\ \text { R20B10D70 } & 20 \% \text { rapeseed oil, } 10 \% \text { n-butanol, } 70 \% \text { diesel } \\ & \text { fuel } \\ \text { R20B20D60 } & 20 \% \text { rapeseed oil, 20\% n-butanol, } 60 \% \text { diesel } \\ & \text { fuel } \\ \text { RCHR } & \text { Relative Cumulative Heat Release } \\ R_{i} & \text { Specific gas constant of air } \\ \text { RSD } & \text { Relative Standard Deviation } \\ \text { SOC } & \text { Start Of Combustion } \\ \text { SOI } & \text { Start Of Injection } \\ T & \text { Temperature of charge in the cylinder } \\ W_{i} & \text { Indicated work } \\ \gamma & \text { Ratio of specific heats at constant pressure } \\ \theta & \text { and volume } \\ & \text { Crankshaft angle }\end{array}$

\section{Introduction}

The emissions of GreenHouse Gases (GHG) and other dangerous pollutants are increasing worldwide and agriculture sector is no exception. The raising energy demands of agriculture sector produce more pollutants and deepen the dependence of most of Europe on imported crude oil products. The partial replacement of fossil diesel with renewable biofuel could decrease the emissions of GHG and dependency on imported fossil fuel products. In an effort to fulfil the targets, established by European Union [3], such as $40 \%$ reduction of GHG emissions by 2030 in comparison with 1990, the first generation biofuels will still be an important tool for GHG reduction [4].

First generation biofuels for compression ignition engines are commonly based on a variety of vegetable oils. For utilization in compression ignition engine it is possible to perform chemical modification of the vegetable oil, such as transesterification [5-9] or hydrogenation [10] in order to decrease the viscosity of the vegetable oil. Alternatively, in order to avoid the energy demanding chemical modification of the fuel it is possible to blend the vegetable oil with diesel fuel or/and alcohol biofuels [11-15].

As the alcohol fuels for diesel engine the ethanol or methanol were tested [16, 17], however, the fuel properties of butanol are closer to the diesel fuel [18-20]. Main advantages of butanol over ethanol and methanol are lower aggression to rubber sealing elements, lower affinity to water, higher cetane number (methanol cetane number $=5$ [21], ethanol cetane number $=8$ [16], butanol cetane number $=17-25[1,22,23])$, better lubricity and higher calorific value [24-27]. Also, the miscibility of vegetable oil in diesel fuel is improved by butanol addition [28]. Butanol can be produced by fermentation process from various sources, including edible and non-edible biomass, such as sugars or lignocellulosic materials $[29,30]$. Also, the butanol can be produced by catalytic conversion of ethanol [31].

In comparison with diesel fuel the ternary fuel blends of butanol, diesel fuel and vegetable oil increase the intensity of premixed phase of the combustion, prolong the ignition delay due to lower cetane number and decrease the combustion duration [13, 20, 32]. Sharon et al. [25] found the increased intensity of premixed combustion with increasing proportion of butanol in diesel fuel-used palm oil blend using atmospheric stationary direct injection engine. Cylinder peak pressure was found to be lower when using vegetable oil-butanol-diesel fuel blends fuel [13, 25, 32] or other fuel blends containing butanol [1, 14, 27, 33, 34] in comparison with diesel fuel. However, Sharon et al. [25] reached slightly higher peak cylinder pressure at low engine load using used palm oil-butanol-diesel fuel blends.

Exhaust gas temperature was found lower with rapeseed oil-butanol-diesel fuel compared with diesel fuel [35], similar results were also reached with fuel blend with cotton oil $[12,19,22,36]$. However, at low engine load the increase of exhaust gas temperature was found with diesel fuel-used palm oil-butanol blends in comparison with diesel fuel [25].

In blend with diesel fuel the butanol also increases the intensity of premixed combustion phase and burning velocity, prolongs ignition delay and decreases the temperatures of exhaust gas [23, 34, 37, 38].

From the viewpoint of fuel consumption the vegetable oil-butanol-diesel fuel blends cause the higher BSFC (Brake Specific Fuel Consumption), mainly due to its lower calorific value $[12,19,22,28,39,40]$. From the viewpoint of efficiency of the engine, the Brake Thermal Efficiency (BTE) was found lower for vegetable oilbutanol-diesel fuel blends in comparison with diesel fuel $[12,22,25,40]$. The lower BTE is explained by lower calorific value and cetane number of n-butanol in the blend. However, the higher concentrations of vegetable oil in the blend tends to increase BTE because of its higher calorific value and cetane number [22].

The solid particles, produced by combustion engines, are one of the most discussed harmful emission component in the present time [41]. The solid particles are composed mainly of carbon (about 50\%), however, the other harmful substances can be absorbed on their surface, such as polycyclic aromatic hydrocarbons, aldehydes and other hydrocarbons [42]. Also the size of the particles is a very important factor concerning the effect on human health, because the very small particles can even enter the blood stream through the alveoli of the lungs [42-44]. The highest deposition efficiency in the alveoli of the lungs was reported for particles in the size of $20 \mathrm{~nm}$ [45].

From the viewpoint of vegetable oil-butanol-diesel fuel blends the lower smoke level was found, especially with increasing proportion of butanol in the fuel blend $[25,28,32]$. On the other hand, Lujaji et al. [32] reached increased smoke density with increasing proportion of vegetable oil in the blend. Lower smoke was also reported for other fuel blends containing butanol [1, 27, 33, 46, 47].

The purpose of the paper was to experimentally determine the influence of rapeseed oil-n-butanol-diesel fuel blends with different concentrations of n-butanol in the fuel 
blend on combustion characteristics, engine efficiency and solid particle emissions of supercharged compression ignition engine. Rapeseed oil was chosen since it is one of the most cultivated energy crop in Europe $[4,48]$ and therefore it has potential to reduce the transport costs and shorten the supply chain.

\section{Materials and methods}

Methodology and the structure of the study are inspired by previous studies of the authors, dealing with combustion characteristics of compression ignition engine fuelled with sunflower oil-n-butanol-diesel fuel blends [49] and with rapeseed oil-diesel fuel blends [50], another study is focused on production of solid particles by compression ignition engine, fuelled with sunflower oil-diesel fuel and rapeseed oil-diesel fuel blends [51].

\subsection{Tested fuels}

For the measurement the mixtures of rapeseed oil, n-butanol and diesel fuel were used as a test fuels. Diesel fuel with no bio-components was used as a reference. The diesel fuel meets the standard EN 590. The following fuel blends were selected for the measurement (the concentrations are per volume):

- $100 \%$ diesel fuel (D100).

- $20 \%$ rapeseed oil, $10 \%$ n-butanol, $70 \%$ diesel fuel (R20B10D70).

- $20 \%$ rapeseed oil, $20 \%$ n-butanol, $60 \%$ diesel fuel (R20B20D60).

The rapeseed oil-n-butanol-diesel fuel blends were chosen in order to test the fuel blend with high bio-content and without requirement for the energy demanding chemical modification of the vegetable oil. Rapeseed oil was used since it is one of the most cultivated energy crop in Europe [4, 48]. The purpose of n-butanol in the blend is mainly to decrease the viscosity of the blend and increase its bio-content. N-butanol was chosen because of its chemical properties which are closer to the diesel fuel than in the case of lower alcohols, as described in the introduction chapter.

The basic fuel properties of tested fuel blends are listed in Table 1. The Stabinger Viscometer SVM 3000 made by Anton Paar GmbH (measuring accuracy $<1 \%$, repeatability $=0.1 \%$ ) was used for measurement of viscosity and density. The calorific values of the fuels were measured using the isoperibol calorimeter LECO AC600 (measuring range $=23.1-57.5 \mathrm{MJ} \mathrm{kg}^{-1}$ for a $0.35 \mathrm{~g}$ sample, accuracy $0.1 \%$ RSD) according to [52] and [53].

\subsection{Equipment used}

For the measurement the tractor engine Zetor 1204, mounted in the tractor Zetor Forterra 8641, was used. The main specification of the engine can be found in Table 2. The engine is turbocharged, unmodified and its operating time reached approx. 160 operating hours.
The injection pressure is given by the manufacturer (Zetor) and before measurement the manual testing device was used for injection pressure check. The start of the injection is kept constant at $12^{\circ} \mathrm{BTDC}$ (before top dead center). The engine is not equipped with a deposit particle filter and meets the regulations according to Tier II as can be seen in Table 3.

The tractor PTO (Power Take Off) shaft was used to load the engine. For that purpose a mobile dynamometer Maha ZW 500 was connected to the tractor PTO. The basic parameters of the dynamometer are listed in Table 4 . Transmission losses have no effect on comparative measurement and therefore they are not taken into account. Data from the dynamometer were recorded via its own data acquisition unit with the frequency of $10 \mathrm{~Hz}$.

During the measurement the cylinder pressure, crankshaft position, fuel consumption, solid particles production, amount of intake air, exhaust gas temperature and ambient conditions (atmospheric pressure, temperature and humidity) were monitored.

The cylinder pressure was measured by means of the piezoelectric pressure sensor Optrand C322-GPA (range = 0-20.7 MPa, accuracy $=1 \%$ ). The pressure sensor was mounted instead of the glow plug. Incremental sensor Sick DKS with 360 pulses per revolution was used for crankshaft position monitoring. Each pulse of the incremental sensor triggers the cylinder pressure record. Therefore, the frequency of cylinder pressure measurement depends on actual engine speed and the resolution of cylinder pressure values is $1^{\circ} \mathrm{CA}$ (Crankshaft Angle).

Laboratory scale Vibra AJ 6200 (range $=0-6200 \mathrm{~g}$, accuracy $=0.1 \mathrm{~g}$, readability $=0.01 \mathrm{~g}$ ) was used for fuel consumption measurement. The laboratory scale was placed under an external fuel tank. Data from the laboratory scale were recorded using RS232 interface with the frequency of $1 \mathrm{~Hz}$.

Engine Exhaust Particle Sizer (EEPS) 3090 made by TSI, Inc. was used for monitoring of the production of solid particles and their distribution. Basic specifications of EEPS are listed in Table 5. The exhaust gas is diluted with air and cooled down to approx. $20-30{ }^{\circ} \mathrm{C}$ before entering EEPS $($ dilution factor $=99.2667$, dilution ratio $=0.01007$ ) The dilution machine and hoses were heated on $150{ }^{\circ} \mathrm{C}$. The pressure of the measured exhaust gas was kept between 80 and $90 \mathrm{kPa}$. Data from EEPS were recorded with the frequency of $1 \mathrm{~Hz}$.

Mass air flow sensor Sierra FastFlo 620S (accuracy = $\pm 1 \%$ of full scale, repeatability $= \pm 0.2 \%$ of full scale) was used for measurement of the amount of intake air. Data from the mass air flow sensor were recorded with a frequency of $10 \mathrm{~Hz}$ using analogue-to-digital converter LabJack U6.

Exhaust gas temperature was measured at the muffler, where the samples for EEPS were taken. Thermocouple type K, connected to Maha data acquisition unit, was used for exhaust gas temperature measurement with the frequency of $10 \mathrm{~Hz}$. Data acquisition unit from Maha is also equipped with sensors for ambient conditions measurement (atmospheric pressure, temperature and humidity). 
Table 1. Basic fuel properties of tested fuel blends and its components.

\begin{tabular}{|c|c|c|c|c|c|c|c|c|}
\hline Fuel & $\begin{array}{l}\text { Kinematic } \\
\text { viscosity } \\
\text { at } 40^{\circ} \mathrm{C} \\
\left(\mathrm{mm}^{2} \mathrm{~s}^{-1}\right)\end{array}$ & $\begin{array}{c}\text { Density } \\
\text { at } 15^{\circ} \mathrm{C} \\
\left(\mathrm{kg} \mathrm{m}{ }^{-3}\right)\end{array}$ & $\begin{array}{c}\text { Calorific } \\
\text { value } \\
\left(\mathrm{MJ} \mathrm{kg}^{-1}\right)\end{array}$ & $\begin{array}{l}\text { Cetane } \\
\text { number }\end{array}$ & $\begin{array}{c}\text { Latent } \\
\text { heat of } \\
\text { evaporation } \\
\left(\mathrm{kJ} \mathrm{kg}^{-1}\right)\end{array}$ & $\begin{array}{c}\text { Carbon } \\
\text { content } \\
(\% \mathrm{wt})\end{array}$ & $\begin{array}{c}\text { Hydrogen } \\
\text { content } \\
(\% w t)\end{array}$ & $\begin{array}{c}\text { Oxygen } \\
\text { content } \\
(\% \mathrm{wt})\end{array}$ \\
\hline D100 & 1.801 & 819.13 & 43.151 & $50^{\mathrm{a}}$ & $250^{\mathrm{b}}$ & 87 & 13 & 0 \\
\hline R20B10D70 & 2.878 & 836.73 & 40.743 & - & - & 82.91 & 12.82 & 4.27 \\
\hline R20B20D60 & 2.860 & 836.53 & 39.817 & - & - & 80.74 & 12.88 & 6.38 \\
\hline n-butanol & 2.266 & 815.27 & 33.101 & $\begin{array}{l}17^{\mathrm{c}}- \\
25^{\mathrm{b}}\end{array}$ & $585^{\mathrm{b}}$ & 64.8 & 13.6 & 21.6 \\
\hline
\end{tabular}

${ }^{\mathrm{a}}$ Data obtained from [54].

${ }^{\mathrm{b}}$ Data obtained from [1] and [23].

${ }^{\mathrm{c}}$ Data obtained from [22].

${ }^{\mathrm{d}}$ Data obtained from [11].

e Data obtained from [55].

Table 2. Engine specification (PTO - Power Take Off).

\begin{tabular}{lc}
\hline Parameter & Specification \\
\hline Manufacturer and type & Zetor, 1204 \\
Cylinders & 4, in-line \\
Air fill & Turbocharged \\
Rated power & $60 \mathrm{~kW}$ at $2200 \mathrm{~min}^{-1}(53.4 \mathrm{~kW} \text { on PTO })^{\mathrm{a}}$ \\
Maximum torque & $351 \mathrm{Nm}$ at $1500 \mathrm{~min}^{-1}(312 \mathrm{Nm} \text { on PTO })^{\mathrm{a}}$ \\
Engine displacement volume & $4.156 \mathrm{~L}$ \\
Cylinder bore X stroke & $105 \times 120 \mathrm{~mm}$ \\
Compression ratio & 17 \\
Fuel supply & Mechanical in-line injection pump \\
Injection type & Direct injection \\
Start Of Injection (SOI) & $12^{\circ} \mathrm{BTDC}$ \\
Injection pressure & $22 \mathrm{MPa}$ \\
Valve mechanism & OHV \\
Valves per cylinder & 2 \\
\hline
\end{tabular}

${ }^{a}$ According to Deutsche Landwirtschafts-Gesellschaft.

\subsection{Measurement methodology}

The schematics of the measurement setup is shown in Figure 1. The measurement was performed in stabilized conditions at a constant rotation speed. The rotation speed of the engine was selected at $1950 \mathrm{~min}^{-1}$. At engine rotation speed $1950 \mathrm{~min}^{-1}$ the PTO shaft reaches the speed of $1000 \mathrm{~min}^{-1}$, which is demanded for proper function of agricultural machines and other equipment, connected to the tractor. Therefore, in normal conditions, the engine spends most of its working time at the rotation speed of $1950 \mathrm{~min}^{-1}$.

The load of the engine was selected at $20 \%, 60 \%$, and $100 \%$. Engine load was calculated from maximum torque at respective rotation speed for each fuel. Table 6 shows the actual reached values of torque and power on PTO
Table 3. Emission regulations Tier II for non-road engines (results of standardized non-road steady cycle according to ISO 8178-4 - type C1).

\begin{tabular}{lc}
\hline Emission component & Limit value $\left(\mathrm{g} \mathrm{kWh}^{-1}\right)$ \\
\hline Carbon monoxide & 5 \\
Hydrocarbons & 1.3 \\
Nitrogen oxides & 7 \\
Particulate matter & 0.4 \\
\hline
\end{tabular}

shaft for each measurement point for all of the tested fuels. In each engine load the monitored parameters were stabilized. After stabilization the monitored parameters were recorded with respective frequency for approx. $80 \mathrm{~s}$. 
Table 4. Dynamometer specification.

\begin{tabular}{lc}
\hline Parameter & Specification \\
\hline Manufacturer and type & Maha ZW 500 \\
Max. power & $500 \mathrm{~kW}$ \\
Max. torque & $6600 \mathrm{Nm}$ \\
Max. speed & $2500 \mathrm{~min}^{-1}$ \\
Torque inaccuracy & $<1 \%$ over the full speed range \\
\hline
\end{tabular}

Table 5. EEPS 3090 specification.

\begin{tabular}{lc}
\hline Parameter & Specification \\
\hline Particle size range & $5.6-560 \mathrm{~nm}$ \\
Particle size resolution & 16 channels per decade \\
& $(32$ total $)$ \\
Electrometer channels & 22 \\
Charger mode of operation & Unipolar diffusion charger \\
Inlet cyclone 50\% cutpoint & $1 \mu \mathrm{m}$ \\
Time resolution & 10 size distributions s \\
\hline
\end{tabular}

\subsection{Combustion analysis}

For the analysis of combustion process the Heat Release Rate (HRR) was calculated. The calculation (1) is based on the first law of thermodynamics and does not take into account the energy losses during the process. However, according to Ozsezen et al. [56, 57], "the temperature gradients, pressure waves, non-equilibrium conditions, fuel vaporization, and mixing can be ignored". The SavitzkyGolay smoothing filter was used on data set for HRR calculation in order to smoothen the data and reduce the noise effects,

$$
\frac{\mathrm{d} Q}{\mathrm{~d} \theta}=\frac{\gamma}{\gamma-1} p \frac{\mathrm{d} V}{\mathrm{~d} \theta}+\frac{1}{\gamma-1} V \frac{\mathrm{d} p}{\mathrm{~d} \theta}
$$

where: $\mathrm{d} Q / \mathrm{d} \theta$ - heat release rate $\left(\mathrm{J} /{ }^{\circ} \mathrm{CA}\right) ; V$ - instantaneous cylinder volume $\left(\mathrm{m}^{3}\right) ; p-$ cylinder pressure $(\mathrm{Pa})$; $\theta$ - crankshaft angle $\left({ }^{\circ} \mathrm{CA}\right) ; \gamma$ - ratio of specific heats at constant pressure and volume (according to [1] and [2] considered constant at 1.35).

From HRR profile, the Relative Cumulative Heat Release (RCHR) was calculated. The heat, released during the combustion was calculated as an integral from HRR, according to equation (2). The RCHR is the ratio between actual cumulative heat release and cumulative heat, released during the whole combustion process and it is expressed in percentage,

$$
Q_{\mathrm{CHR}}=\int_{\mathrm{EOC}}^{\mathrm{SOC}} \frac{\mathrm{d} Q}{\mathrm{~d} \theta} \mathrm{d} \theta
$$

where: $Q_{\mathrm{CHR}}-$ Cumulative Heat Release $(\mathrm{J})$; SOC Start Of Combustion $\left({ }^{\circ} \mathrm{CA}\right)$; EOC - End Of Combustion $\left({ }^{\circ} \mathrm{CA}\right)$.

The indicated efficiency, Brake Thermal Efficiency (BTE) and Brake Specific Fuel Consumption (BSFC) were

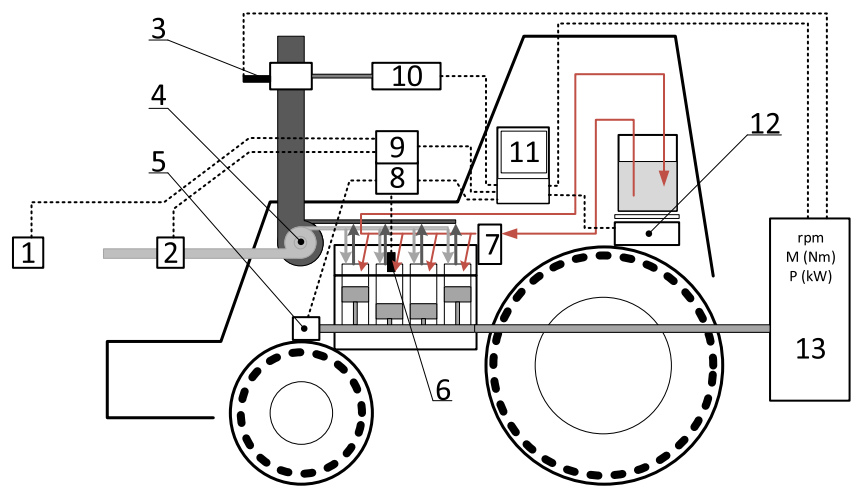

(a)

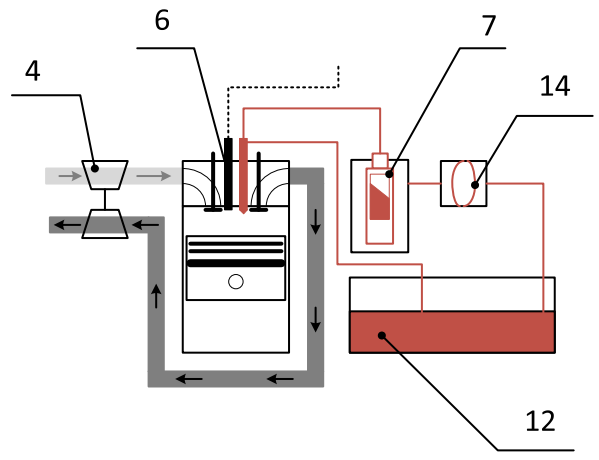

(b)

Fig. 1. (a) Measurement scheme, (b) detailed schematics of engine: 1 - sensor of pressure and temperature of intake air, 2 - mass air flow sensor, 3 - exhaust gas temperature sensor, 4 - turbocharger, 5 - incremental sensor of crankshaft position and rotation speed, 6 - cylinder pressure sensor, 7 - injection pump, 8 - data acquisition unit for cylinder pressure sensor and crankshaft position speed sensor, 9 - A/D converter LabJack U6, 10 - EEPS, 11 - PC for control and data record, 12 - Laboratory scale with external fuel tank, 13 - dynamometer, 14 - fuel pump.

Table 6. Values of torque and power for all tested fuels at

\begin{tabular}{|c|c|c|c|c|c|c|}
\hline \multirow{2}{*}{$\begin{array}{l}\text { Engine } \\
\text { load }\end{array}$} & \multicolumn{2}{|c|}{ D100 } & \multicolumn{2}{|c|}{ R20B10D70 } & \multicolumn{2}{|c|}{ R20B20D60 } \\
\hline & $\mathrm{Nm}$ & $\mathrm{kW}$ & $\mathrm{Nm}$ & $\mathrm{kW}$ & $\mathrm{Nm}$ & $\mathrm{kW}$ \\
\hline $20 \%$ & 204 & 11.74 & 197.13 & 11.34 & 198.36 & 11.41 \\
\hline $60 \%$ & 558.95 & 32.17 & 537.97 & 30.96 & 557.69 & 32.09 \\
\hline $100 \%$ & 900.62 & 51.84 & 883.88 & 50.86 & 875.96 & 50.41 \\
\hline
\end{tabular}
all tested loads.

also calculated from the measured and calculated data. The indicated efficiency is a ratio between indicated work and energy, given in the fuel. Indicated work was calculated as the area inside the $p-V$ diagram according to equation (3). According to [58] only compression and expansion strokes were taken into account for indicated work calculation in order to exclude gas exchange from the result,

$$
W_{i}=\int_{180}^{-180} p \mathrm{~d} V .
$$


SOC was determined from the HRR profile. From the HRR the SOC can be determined in two ways. According to [2] or [59] the SOC can be defined by a change in slope of HRR curve. However, due to the relatively low resolution of $1^{\circ} \mathrm{CA}$ it would be difficult to establish the change in slope with the sufficient accuracy. Another author [1] state, that SOC occurs once the HRR curve becomes positive. This moment was considered as the SOC, EOC was defined by the moment when HRR curve becomes negative.

Temperature of charge in the cylinder also provides important information about the combustion process and conditions before SOC. The temperature in the cylinder was calculated according to the ideal gas law and equation (4). The calculation does not take into account heat losses during the process,

$$
T=\frac{p V}{m R_{i}},
$$

where: $T$ - temperature of charge in the cylinder $(\mathrm{K}) ; m-$ mass air flow per cycle $(\mathrm{kg}) ; R_{i}$ - specific gas constant of air $\left(\mathrm{J} \mathrm{kg}^{-1} \mathrm{~K}^{-1}\right)$.

\section{Results and discussion}

\subsection{Combustion characteristics}

In Figure 2 the cylinder pressure in dependence on crankshaft position at $20 \%$ engine load for all tested fuels is shown. It is evident that SOC appears after the top dead center at low engine load. Course of the cylinder pressure before SOC is affected by fuel evaporation and energy losses during compression, so that maximum compression pressure appeared approx. $2-3^{\circ}$ BTDC. The n-butanol in the fuel blends also caused higher decrease of cylinder pressure during Ignition Delay (ID) by its higher heat of evaporation and higher volatility in comparison with D100. A similar result, concerning increased cooling effect of n-butanol evaporation was also reached in other studies with turbocharged [1] and atmospheric engine [60].

It can be seen that the fuel blends, containing n-butanol, reached significantly lower cylinder pressure during compression and expansion strokes in comparison with D100. Cylinder peak pressure was lower using fuel blend B20B10D70 by approx. $12.5 \%$ and R20B20D60 by $8.4 \%$ compared with D100. This is connected with lower mass air flow through the engine and lower calorific value of the blended fuels. Also it may be noted that fuel blends with a higher proportion of bio-components (R20B20D60) reached higher peak cylinder pressure than R20B10D70.

In Figure 3 the HRR and RCHR in dependence on crankshaft position for all measured fuels at $20 \%$ engine load is shown, the detailed curves of HRR during premixed combustion phase can be seen in Figure 4. It can be seen that the combustion duration was shorter for fuel blends in comparison with D100 by approx. 14\%. Also, heat released during combustion process was lower for R20B10D70 and R20B20D60 fuel blends than for D100. In particular, combustion of R20B10D70 released by $28.41 \%$ lower heat and R20B20D60 by $25.79 \%$. Ignition

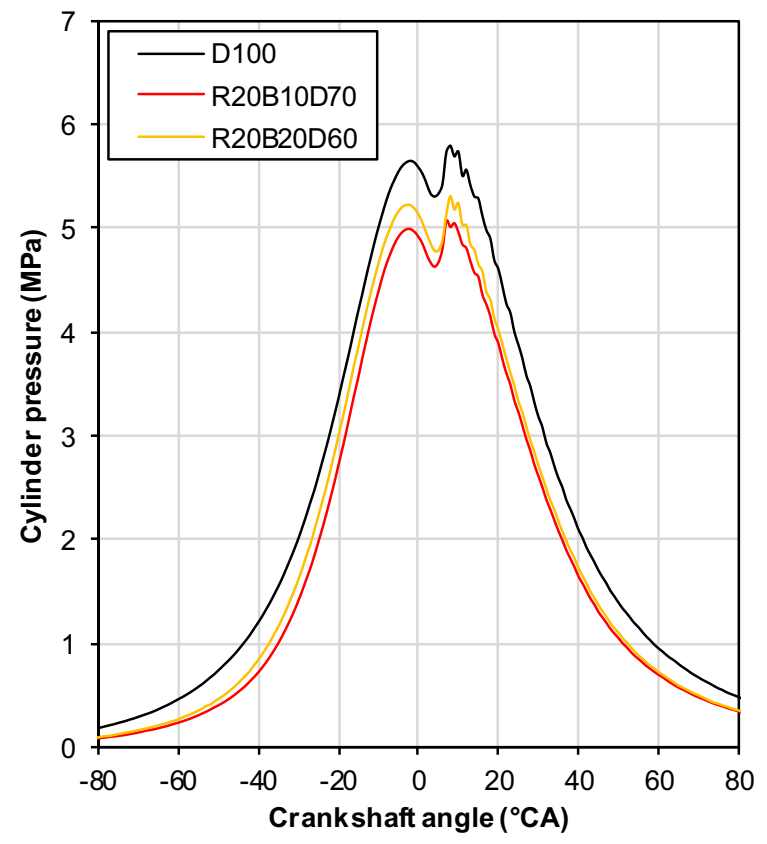

Fig. 2. Cylinder pressure for all tested fuels at $20 \%$ engine load.

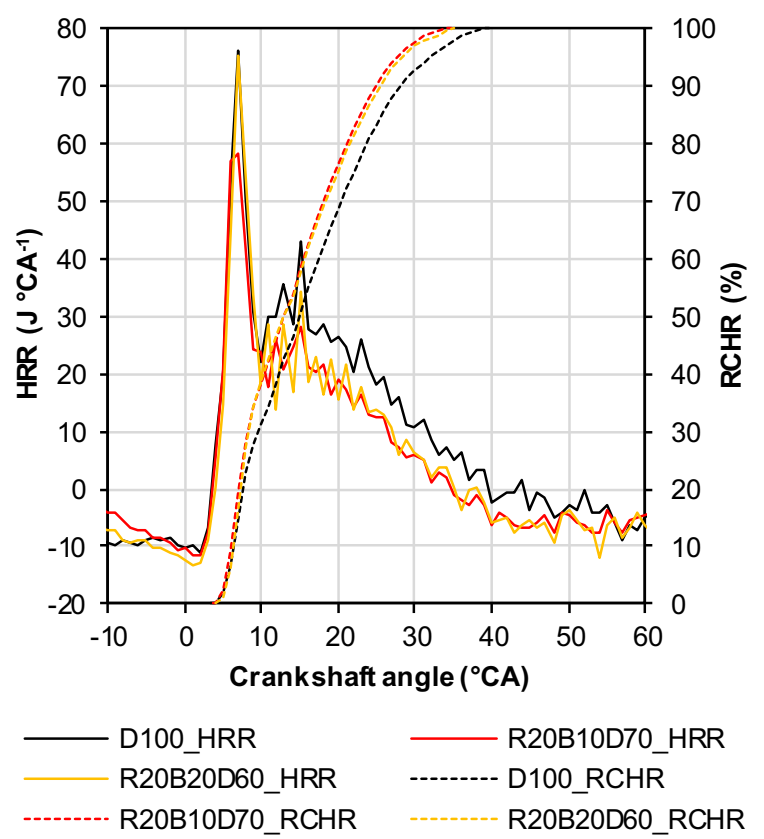

Fig. 3. HRR and RCHR for all tested fuels at $20 \%$ engine load.

delay was prolonged for R20B10D70 by $0.72 \%$ and by $3.37 \%$ for R20B20D60.

The heat, released during premixed combustion phase (first peak on HRR curve after SOC), was in absolute values higher for D100 (by $27.71 \%$ in comparison with R20B10D70 and by $6.76 \%$ in comparison with R20B20D60), however, RCHR at the end of premixed combustion was higher for the fuel blends compared with D100 (D100 - 31.12\%， R20B10D70 - 34.04\%, 


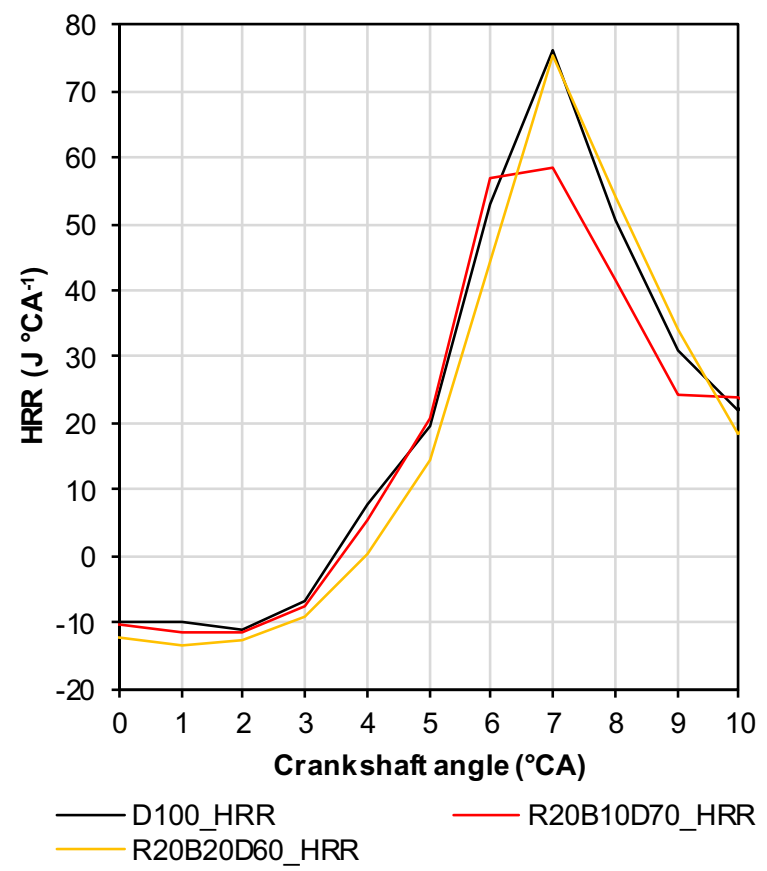

Fig. 4. Detailed HRR during premixed combustion phase for all tested fuels at $20 \%$ engine load.

R20B20D60 - 38.76\%). Diffusion and late combustion phases were shorter for both of the blended fuels compared with D100. Also, lower amount of heat was released during diffusion and late combustion phases (by $31.44 \%$ for R20B10D70 and by $33.14 \%$ for R20B20D60) in comparison with D100. Less intensive diffusion and late combustion phases may be caused by the combination of lower calorific value of the blended fuels (injected mass and energy content of the fuels can be seen in Tab. 9) and relatively more fuel burned in the premixed phase of combustion.

In Figure 5 the temperature of charge in the cylinder in dependence on crankshaft position at $20 \%$ engine load can be seen. It is evident that with blended fuels, the significantly higher temperature was reached during combustion. The peak temperature of charge in the cylinder was higher by $7.64 \%$ when using R20B10D70 and by $9.94 \%$ when using R20B20D60. Rakopoulos et al. [34] found slightly lower cylinder temperature with n-butanol-diesel fuel blends in comparison with diesel fuel, the same author in another study [33] found increased cylinder temperature during combustion after adding n-butanol into cottonseed oil and its biodiesel. Chen et al. [38] found higher mean gas temperature using 30\% butanol-diesel fuel blend. From the calculation according to equation (4) the lower mass of charge is the main cause of the increased temperature of charge in the cylinder as the cylinder pressure was lower than in the case of D100. Lower mass of charge in the cylinder has lower heat capacity and reaches higher temperature during combustion of the fuel. Also, the evaporation of the fuel blends after injection during ID (approx. $-12^{\circ}$ to $4^{\circ} \mathrm{CA}$ ) caused higher decrease of cylinder temperature before SOC than in the case of D100. This can be attributed to relatively high heat of evaporation of n-butanol in the fuel

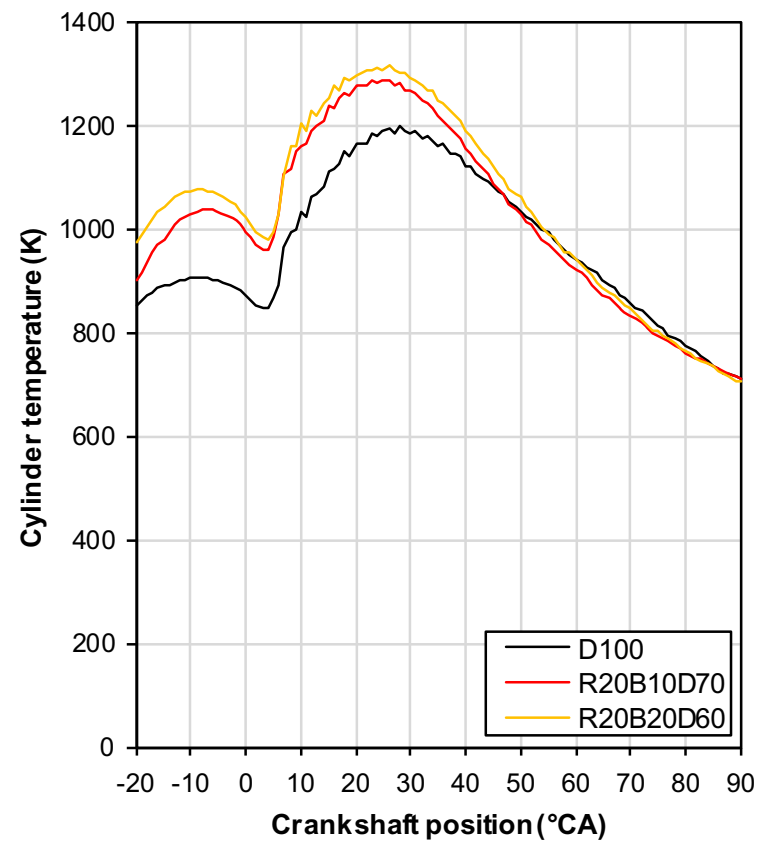

Fig. 5. Temperature of charge in the cylinder for all tested fuels at $20 \%$ engine load.

blends and its higher volatility in comparison with D100. Moreover, it may be noted that higher temperature of charge was observed at SOI when using the blended fuels in comparison with D100.

In Figure 6 the cylinder pressure in dependence on crankshaft position at $60 \%$ engine load for all tested fuels is shown. Similarly to $20 \%$ engine load, lower cylinder pressure was reached using both of the fuel blends during both compression and expansion strokes. The peak cylinder pressure was lower by $11.56 \%$ using R20B10D70 and by $7.87 \%$ using R20B20D60 fuel blend. As in the case of 20\% engine load this decrease of cylinder pressure can be explained by lower air flow through the engine and lower calorific value of the blended fuels. Cylinder pressure decrease during ID, caused by evaporation of the fuel was not as significant as at $20 \%$ engine load since ID was shorter at $60 \%$ engine load.

HRR and RCHR for all tested fuels at $60 \%$ engine load can be seen in Figure 7, the detailed curves of HRR during premixed combustion phase are shown in Figure 8. Combustion of both of the blended fuels released lower amount of heat in comparison with D100. For R20B10D70 the decrease was approx. $18.91 \%$ and for R20B20D60 approx. $16.72 \%$. Also, from the figure it is evident that combustion duration was shorter when using both of the blended fuels (by $12.2 \%$ when using R20B10D70 and by $11.29 \%$ when using R20B20D60). ID was shortened at this engine load by approx. $0.52 \%$ when using R20B10D70 and by $0.17 \%$ when using R20B20D60 fuel blend.

Premixed combustion phase was longer by $1^{\circ} \mathrm{CA}$ for R20B10D70 and R20B20D60 in comparison with D100. During longer premixed combustion phase, higher amount of heat was released when combusting both of the blended fuels (by 27.3\% for R20B10D60 and by $45.9 \%$ for 


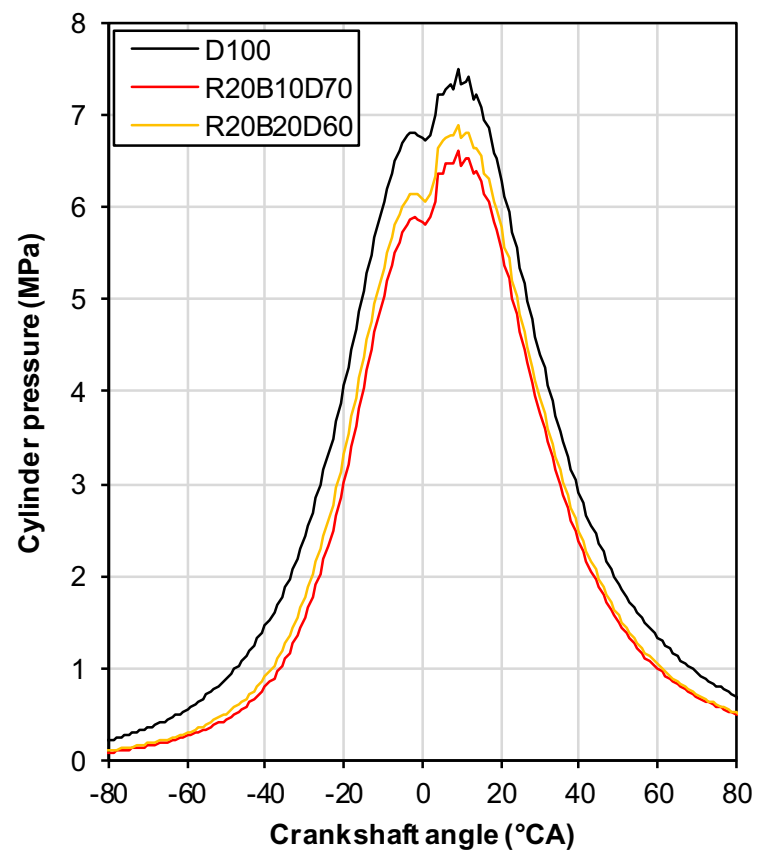

Fig. 6. Cylinder pressure for all tested fuels at $60 \%$ engine load.
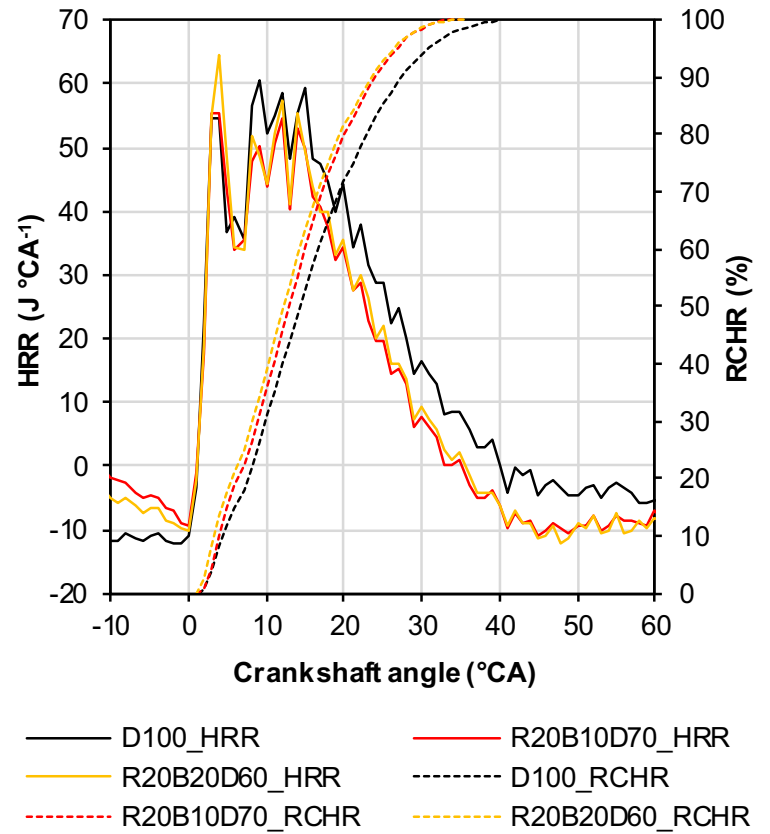

Fig. 7. HRR and RCHR for all tested fuels at $60 \%$ engine load.

R20B20D60 in comparison with D100). Moreover, the highest peak HRR during premixed combustion phase can be seen for R20B20D60. RCHR at the end of the premixed combustion was also higher for both of the blended fuels (D100 - 11.96\%, R20B10D70 - 18.78\%, R20B20D60 $20.96 \%$ ). This may be explained by the amount of n-butanol, its volatility and high oxygen content. Similar results concerning the increased intensity of premixed combustion

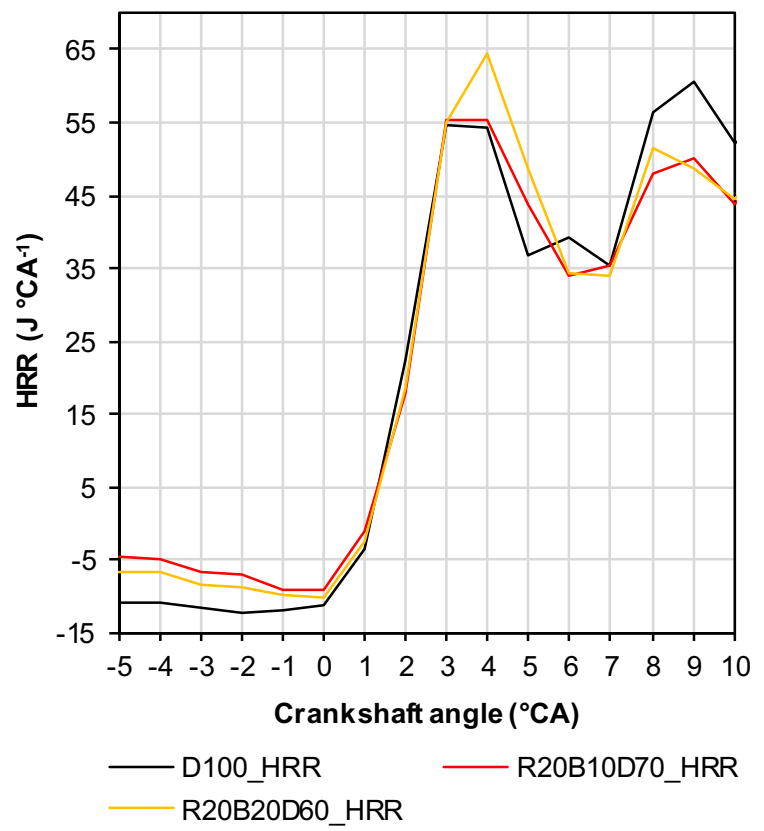

Fig. 8. Detailed HRR during premixed combustion phase for all tested fuels at $60 \%$ engine load.

phase were reached by other authors with vegetable oilbutanol-diesel fuel blends in comparison with diesel fuel [25, 32, 38], while with the increasing proportion of the butanol the effect was more significant. According to [25, 38 this can be explained by higher ID, caused by lower cetane number of butanol and its higher oxygen content.

Similarly to $20 \%$ engine load the diffusion and late combustion phases are shorter and less intensive using both of the blended fuels in comparison with D100 and for both of the blended fuels it was nearly identical. The heat, released during diffusion and late combustion phases was lower by $25.2 \%$ when using R20B10D70 and by $25.23 \%$ when using R20B20D60 fuel blend compared with D100.

In Figure 9 the temperature of charge in the cylinder in dependence on crankshaft position at $60 \%$ engine load can be seen. During the combustion the blended fuels reached higher temperature of charge in comparison with D100 (R20B10D70 by $12.49 \%$ and R20B20D60 by $15 \%$ ). Similarly to $20 \%$ engine load, the higher temperature of charge for blended fuels can be explained mainly by lower mass air flow and higher oxygen content of the blended fuels.

In Figure 10 the cylinder pressure in dependence on crankshaft position at full engine load for all tested fuels is shown. It is evident that the cylinder pressure curves for both of blended fuels are nearly identical. The peak cylinder pressure was lower for R20B10D70 by $8.1 \%$ and by $7.67 \%$ for R20B20D60. The lower cylinder pressure of the blended fuels can be explained by lower mass air flow and thus lower mass of charge in the cylinder and lower calorific value of blended fuel compared with D100.

In Figure $11 \mathrm{HRR}$ and RCHR in dependence on crankshaft position for all tested fuels at full engine load can be seen, the detailed curves of HRR during premixed combustion phase are shown in Figure 12. In comparison with 


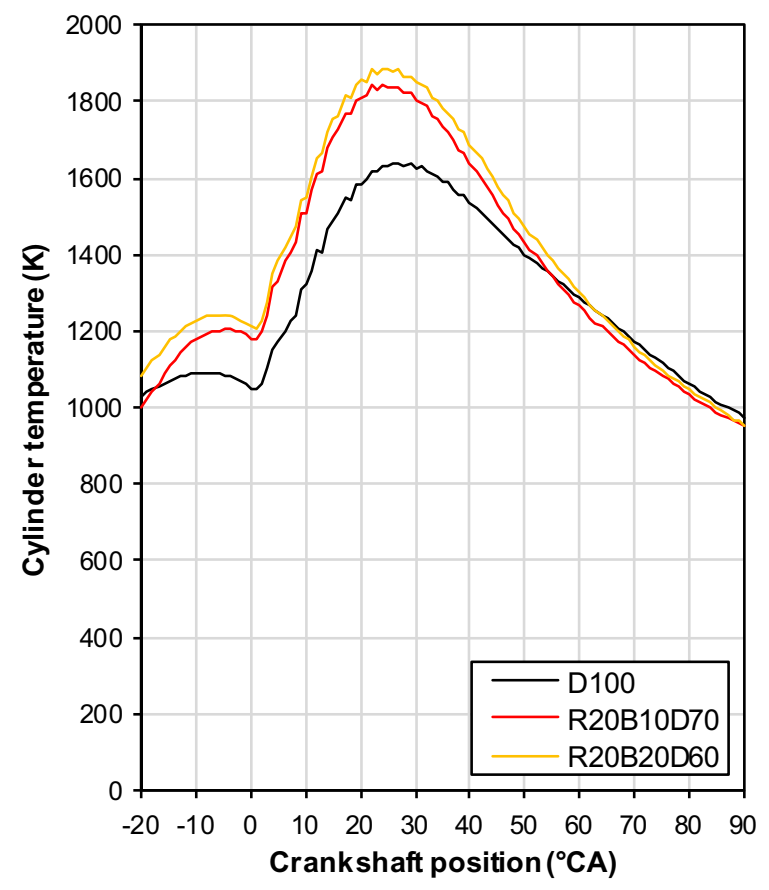

Fig. 9. Temperature of charge in the cylinder for all tested fuels at $60 \%$ engine load.

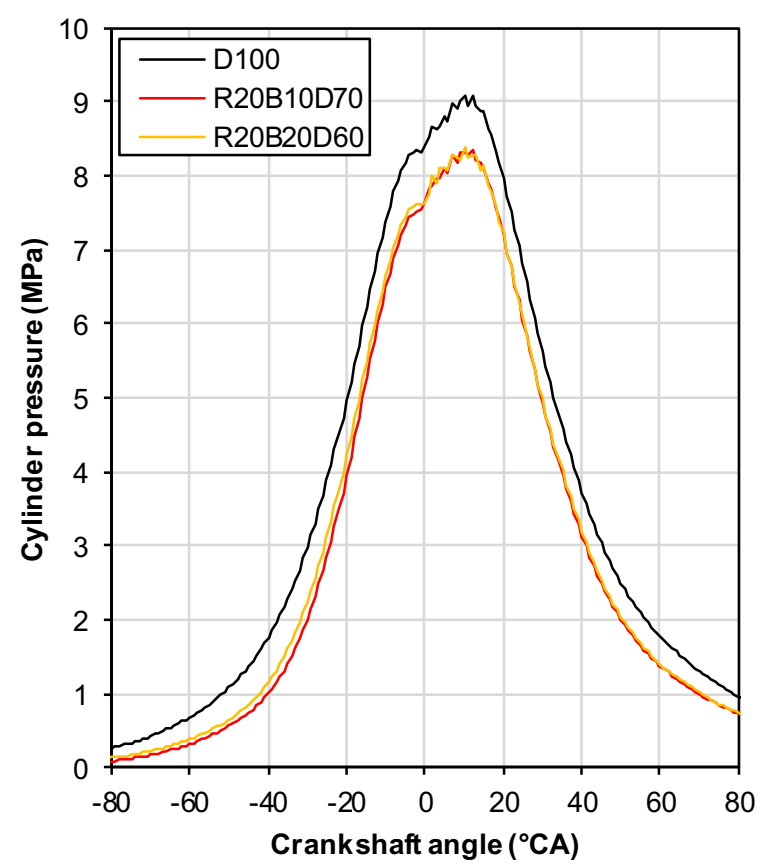

Fig. 10. Cylinder pressure for all tested fuels at $100 \%$ engine load.

D100 the combustion duration was shorter by $10.16 \%$ when using fuel blend R20B10D70 and by $10.45 \%$ when using fuel blend R20B20D60. Heat, released during the combustion process was lower by $17.88 \%$ in the case of R20B10D70 and by $16.89 \%$ in the case of R20B20D60 in comparison

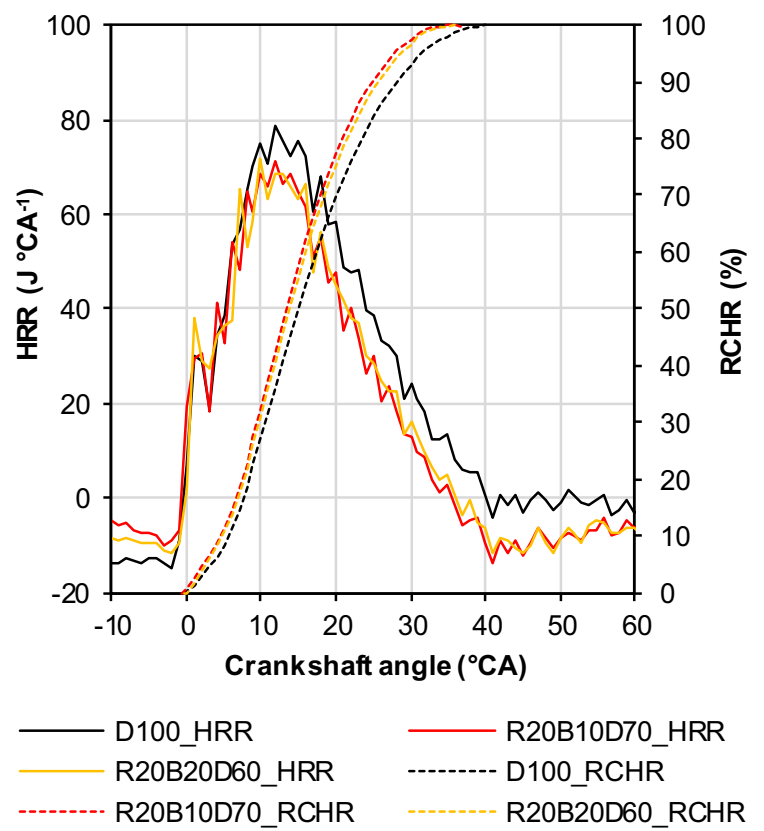

Fig. 11. HRR and RCHR for all tested fuels at $100 \%$ engine load.

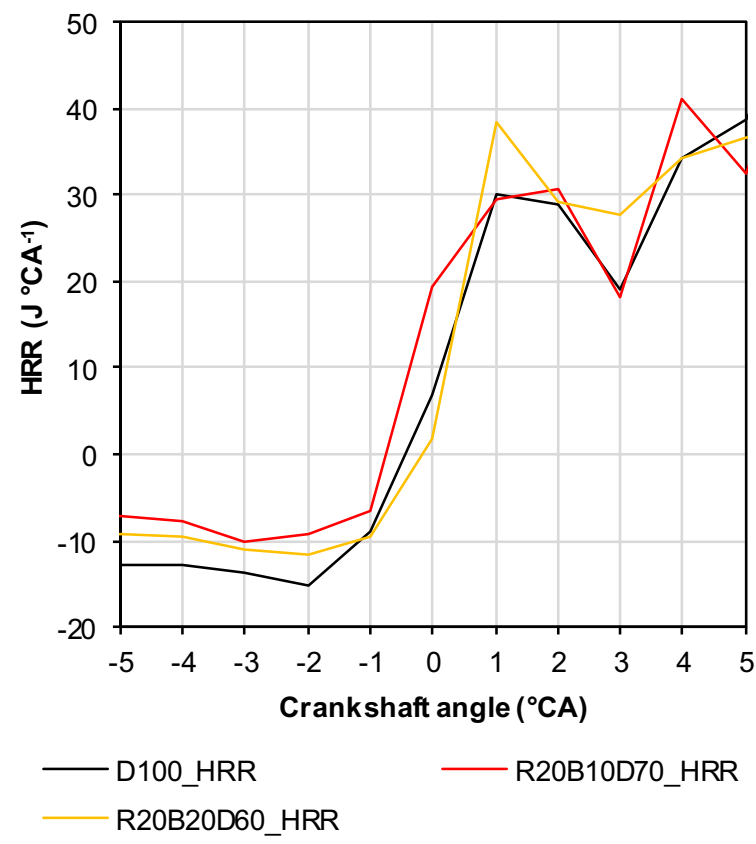

Fig. 12. Detailed HRR during premixed combustion phase for all tested fuels at 100\% engine load.

with D100. When using R20B10D70 fuel blend ID was shortened by approx. $2.66 \%$, on the contrary, when using R20B20D60 fuel blend ID was prolonged by approx. $2.39 \%$ in comparison with D100. ID was affected by cetane number of the fuels and temperature of charge in the cylinder at SOI. 


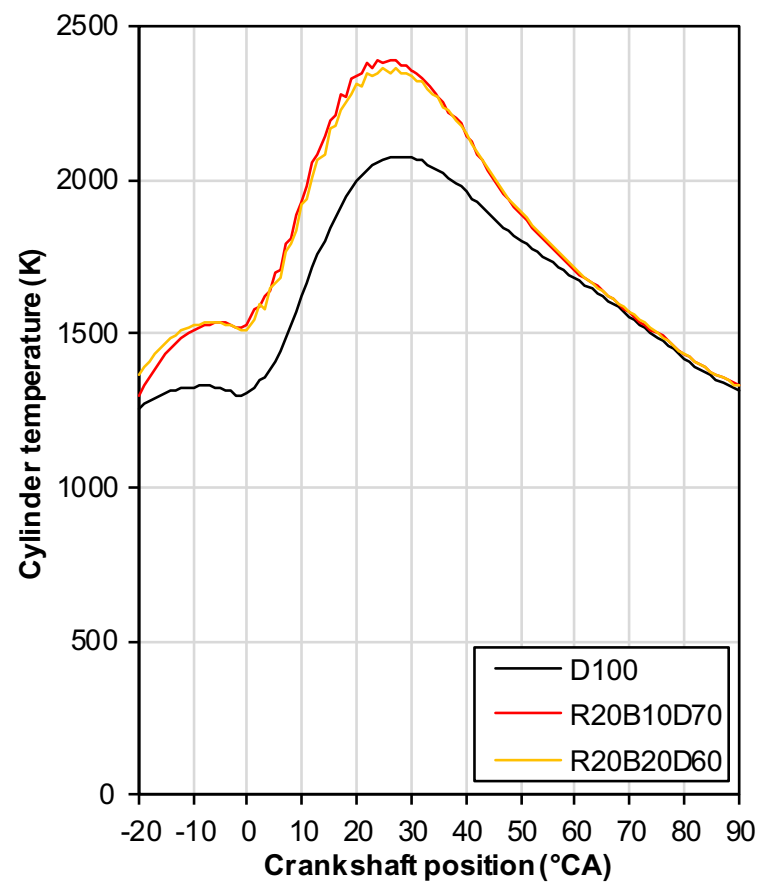

Fig. 13. Temperature of charge in the cylinder for all tested fuels at $100 \%$ engine load.

Similarly to $60 \%$ engine load, the higher intensity of premixed combustion phase can be seen when using both of the blended fuels (by $17.2 \%$ for R20B10D70 and by $12.21 \%$ for R20B20D60 compared with D100). RCHR at the end of premixed combustion phase was $4.49 \%$ for D100, $6.41 \%$ for R20B10D70 and $6.06 \%$ for R20B20D60. Also, highest peak of HRR can be seen during premixed combustion phase when using R20B20D60. Lower intensity of premixed combustion phase for R20B20D60 in comparison with R20B10D70 was caused by longer ID of R20B20D60 fuel blend, caused by low cetane number of the n-butanol, contained in the blend. Therefore, the duration of premixed combustion phase was shorter for R20B20D60. Diffusion and late combustion phases were less intensive for both of blended fuels in comparison with D100. The heat, released during diffusion and late combustion phases was lower by $19.5 \%$ when using R20B10D70 and by $18.25 \%$ when using R20B20D60. Lower heat, released during diffusion and late combustion phases may be caused calorific value of the blended fuels in comparison with D100.

The temperature of charge in the cylinder in dependence on crankshaft position at full engine load is shown in Figure 13. It can be seen, that during combustion both of the fuel blends reached significantly higher temperature of charge in the cylinder compared with D100 (R20B10D70 by $15.14 \%$ and R20B20D60 by $13.87 \%$ ), similarly to $20 \%$ and $60 \%$ engine load. The temperature decrease before SOC during ID was not as significant as at in the case of $20 \%$ and $60 \%$ engine load since ID was shorter and SOC appeared before top dead center.

In Figure 14 ID and combustion duration are shown. The shorter combustion duration of both of the blended fuels can be explained by stronger premixed combustion
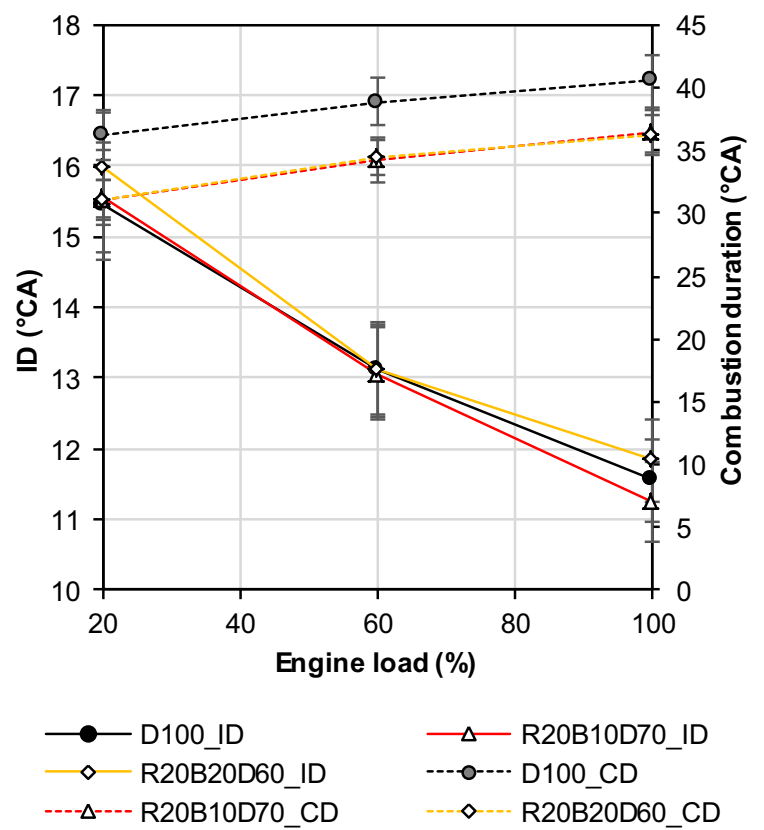

Fig. 14. Ignition delay and combustion duration for all tested fuels at all measured loads (CD - Combustion Duration) (error bars represent $95 \% \mathrm{CI}$ ).

phase, during which higher proportion of fuel was burned when using blended fuels, since RCHR reached higher values at the end of the premixed combustion phase in comparison with D100. Also, higher oxygen content and relatively simple molecule of $\mathrm{n}$-butanol contributes to faster oxidization.

Shorter ID, reached with R20B10D70 fuel blend, particularly at $60 \%$ and $100 \%$ engine load may be caused by higher temperature of charge in the cylinder at SOI, which causes earlier ignition of the fuel. Also, rapeseed oil, contained in the fuel blends may contributed to shorter ID by its physical and chemical properties, since vegetable oils were found to decrease ID in blends with diesel fuel $[25,50,61,62]$. Lujaji et al. [32] found shorter ignition delay with blend of $80 \%$ diesel fuel, $15 \%$ croton oil and $5 \% \mathrm{n}$-butanol at low engine load in comparison with diesel fuel.

In the case of R20B20D60 fuel blend the ID was prolonged at $20 \%$ and $100 \%$ engine load. The prolonged ID was caused by low cetane number of the fuel blend as a result of $20 \%$ proportion of n-butanol. Increased ID was also observed by other authors when using vegetable oil-butanol-diesel fuel blends, especially with increasing proportion of butanol $[25,32]$. Similar results were reached also with other fuel blends containing butanol [1, 33, 34, 38]. The authors also explain the increased ID and later SOC by lower cetane number of butanol.

In Figures 2, 6 and 10 the lower cylinder pressure during compression and expansion strokes for both of blended fuels can be seen at all tested engine loads. The lower cylinder pressure was caused by lower mass air flow through the engine, as can be seen in Figure 15 and Table 7. The lower mass air flow may be a result of lower speed of 


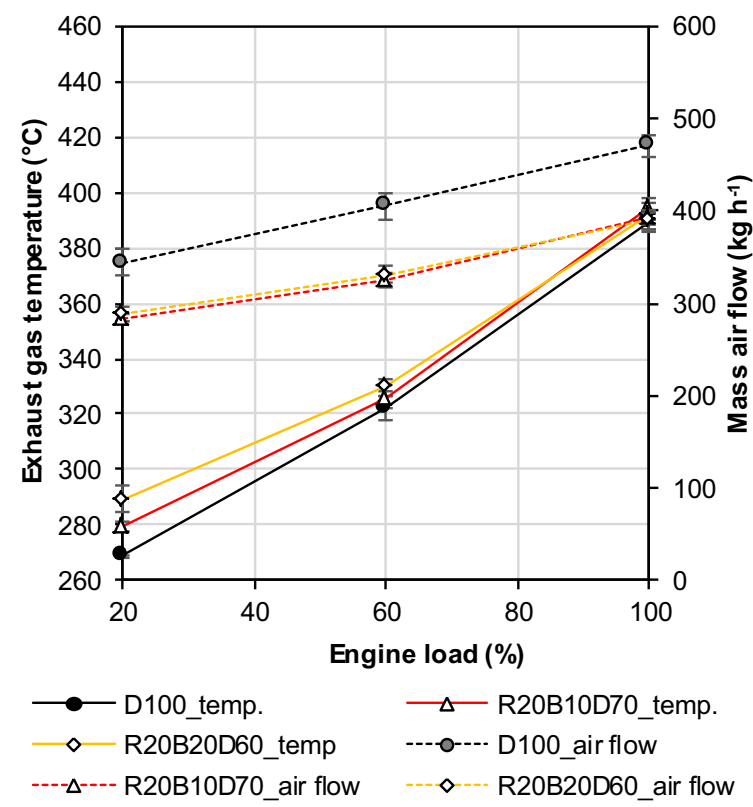

Fig. 15. Exhaust gas temperature and engine mass air flow for all tested fuels at all measured loads (error bars represent the value of standard deviation).

Table 7. Mass air flow for all tested fuels at all measured loads.

\begin{tabular}{lccc}
\hline $\begin{array}{l}\text { Engine load } \\
(\%)\end{array}$ & $\begin{array}{c}\mathrm{D} 100 \\
\left(\mathrm{~kg} \mathrm{~h}^{-1}\right)\end{array}$ & $\begin{array}{c}\mathrm{R} 20 \mathrm{~B} 10 \mathrm{D} 70 \\
\left(\mathrm{~kg} \mathrm{~h}^{-1}\right)\end{array}$ & $\begin{array}{c}\mathrm{R} 20 \mathrm{~B} 20 \mathrm{D} 60 \\
\left(\mathrm{~kg} \mathrm{~h}^{-1}\right)\end{array}$ \\
\hline 20 & 344.29 & 265.77 & 270.06 \\
60 & 405.07 & 303.87 & 309.65 \\
100 & 470.18 & 366.98 & 364.73 \\
\hline
\end{tabular}

turbocharger. Speed of turbocharger depends on kinetic energy of exhaust gas. Lower kinetic energy of gas may be connected earlier EOC, reached with both blended fuels at all tested engine loads in comparison with D100.

Temperature of exhaust gas for all tested fuels at all measured engine loads is shown in Figure 15. It can be seen that temperature of exhaust gas was higher for both of tested fuel blends in comparison with D100. Statistically significant difference in exhaust gas temperature was found between all tested fuels at all measured loads. ANOVA for exhaust gas temperature at $100 \%$ engine load, complemented with Tukey HSD post-hoc test is shown in Table 8 . Higher temperature of exhaust gas, reached with the fuel blends, is connected with temperature of charge in the cylinder reached during combustion, which was higher for the blended fuels. Also, it can be seen, that the differences in exhaust gas temperature are decreasing with increasing engine load. In general, most of other authors found lower exhaust gas temperature after butanol addition into diesel fuel, vegetable oil, biodiesel or their blends $[12,13,19,23$, $36,63,64]$, which was by most of authors explained by higher volatility and heat of evaporation of butanol in the fuel blend. However, Sharon et al. [25] observed higher exhaust gas temperature with used palm oil-n-butanoldiesel fuel blend at $0 \%$ engine load in comparison with diesel fuel using atmospheric diesel engine.

The exhaust gas with higher temperature heats the turbocharger to a higher temperature in comparison with D100. The turbocharger with a higher temperature causes more intensive heat transfer between exhaust gas and intake air. Moreover, decreased air flow also contributes to higher temperature of charge in the cylinder and affects ID. As a result, lower amount of air with a higher temperature was delivered into the cylinder.

From Figures 3, 7, and 11 it is evident that combustion of the both of tested fuel blends released significantly lower amount of heat in comparison with D100. However, lower mass of charge in the cylinder, caused by lower speed of turbocharger, takes less energy during the compression stroke. As a result, when using the fuel blends the indicated work, shown in Figure 16, reached comparable values with D100. The highest difference was reached with fuel blend R20B20D60 at 20\% engine load (approx. 10\%). At 60\% and $100 \%$ engine loads the difference of indicated work between fuel blends and D100 was under $4 \%$.

\subsection{Engine efficiency}

In Figure 16 the indicated efficiency of the engine, reached with all tested fuels at all measured engine loads, can be seen. It is evident that R20B10D70 reached at all measured loads highest indicated efficiency, especially at $60 \%$ and $100 \%$ engine loads.

Figure 17 shows BSFC and BTE, reached with all tested fuels in all measured engine loads. It is evident that BSFC was higher for both of the blended fuels at all measured engine loads in comparison with D100. Highest increase of BSFC was reached using R20B20D60 at $60 \%$ $(6.57 \%)$ and $100 \%(7.23 \%)$ engine load. At $20 \%$ engine load the difference between R20B10D70 and R20B20D60 is on the border of measurement accuracy of the used equipment. Increase of BSFC is given by the lower calorific values of the fuel blends in comparison with D100. In other studies the increased BSFC in comparison with diesel fuel was observed when using n-butanol-vegetable oil-diesel fuel blends [12, 19, 22], vegetable oil-diesel fuel blends [61] and n-butanol-diesel fuel blends [23]. The actual values of injected fuel mass and its energy content for all measured loads can be seen in Table 9. The slight differences are given by different calorific values and densities of the measured fuels since the fuels are injected on the volumetric basis. Also, the measured point setting accuracy affects the amount of injected fuel. At $100 \%$ engine load the difference in the amount of the injected fuels is given only by the fuel density as the volumetric amount is the same.

At 20\% engine load BTE reached values of approx. $15 \%$ (D100 - 15.06\%, R20B10D70 - 15.46\%, R2B20D60 $15.51 \%$ ), at $60 \%$ load the engine reached BTE approx. $26 \%$ (D100 - 26.41\%, R20B10D70 - 26.55\%, R2B20D60 $26.26 \%)$ and at full engine load BTE reached approx. $30 \%$ (D100 - 29.7\%, R20B10D70 - 29.72\%, R20B20D60 $29.36 \%$ ). It is evident, that the differences of BTE, reached by blended fuels in comparison with D100 were under $0.5 \%$. 
Table 8. ANOVA with Tukey HSD post-hoc test for exhaust gas temperature at $100 \%$ engine load.

\begin{tabular}{lcccc}
\hline$\alpha=0.05$ & Sum of squares & Degrees of freedom & Variance & $F$-value \\
\hline Between groups & 9892.6728 & 2 & 4946.3364 & 266.9985 \\
Within groups & 48759.6652 & 2632 & 18.5257 & - \\
Total & 58652.3379 & 2634 & - & - \\
\hline
\end{tabular}

Tukey HSD post-hoc test.

D100 vs. R20B10D70: Diff $=4.6906,95 \% \mathrm{CI}=4.2145$ to $5.1668, p=0.0000$.

D100 vs. R20B20D60: Diff $=2.0543,95 \% \mathrm{CI}=1.5757$ to $2.5328, p=0.0000$.

R20B10D70 vs. R20B20D60: Diff $=-2.6364,95 \% \mathrm{CI}=-3.1284$ to $-2.1443, p=0.0000$.

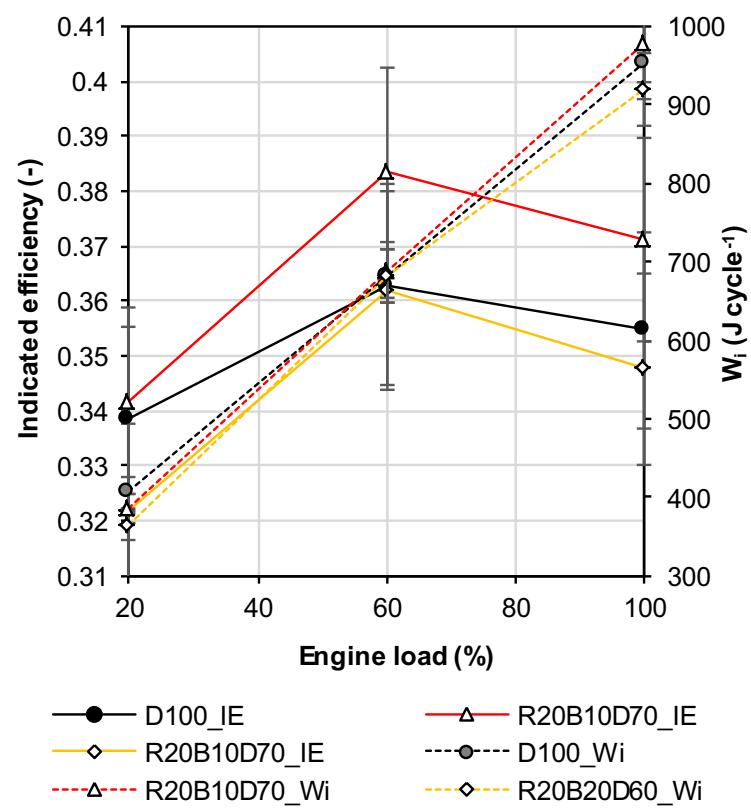

Fig. 16. Indicated efficiency and indicated work for all tested fuels at all measured loads (error bars represent 95\% CI).

However the higher amount of n-butanol in the fuel blend R20B20D60 tends to slightly decrease BTE at 100\% engine loads, caused by longer ID. On the contrary, at $20 \%$ engine load both of the blended fuels slightly increased BTE. Most of the authors found decreased engine BTE when using vegetable oil-butanol-diesel fuel blends [12, 22, 25, 32, 36, 40]. Atmanli et al. [12] explain this phenomenon by lower calorific value and cetane number and higher viscosity of the vegetable oil-butanol-diesel fuel blends which provides lower heat release and thus less useful work and lower BTE. However, other fuel blends containing butanol were found to increase BTE $[17,33,65]$.

\subsection{Solid particles production}

In Figure 18 the result of particle analysis for all tested fuels at $20 \%$ engine load is shown. It is evident that both of the blended fuels reached lower amount of produced solid particles in comparison with D100. Maximum concentration of solid particles in the exhaust gas decreased by $19.83 \%$ in the case of R20B10D70 and by $20.95 \%$ in the case

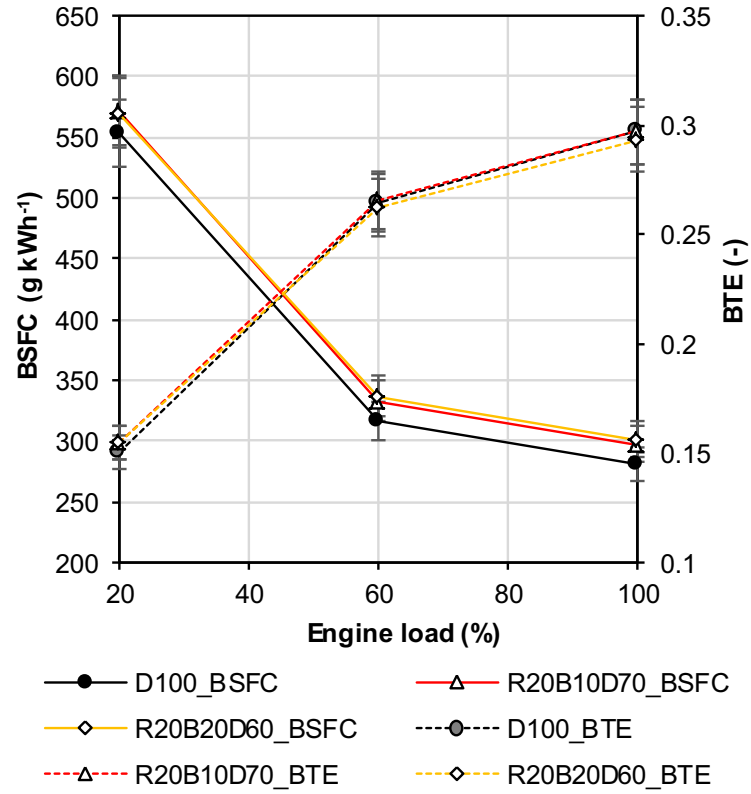

Fig. 17. BSFC and BTE for all tested fuels at all measured loads (error bars represent 95\% CI).

of R20B20D60 in comparison with D100. The decrease of solid particles concentration was caused by relativelly high oxygen content in the fuel blends in comparison with D100. The mean size of particles with highest concentration also decreased from $60.4 \mathrm{~nm}$ reached with D100 to $52.3 \mathrm{~nm}$ reached with both of the fuel blends. Moreover, higher concentration of n-butanol in fuel blend R20B20D70 caused increase of solid particles production with the mean sizes 19.1-39.2 nm in comparison with R20B10D70. On the contrary, R20B10D70 reached higher concentrations of solid particles in the mean size range $93.1-294.3 \mathrm{~nm}$ in comparison with R20B20D60 fuel blend. Similar results were reached by Geng et al. [66] when using waste cooking oil biodiesel-n-butanol blends, particularly smaller mean diameter of particles and lower concentration in comparison with diesel fuel with increasing proportion of the n-butanol using turbocharged diesel engine equipped with common rail.

Figure 19 shows the result of particle analysis for all measured fuels at $60 \%$ engine load. Similarly to $20 \%$ engine load, the maximum concentrations, reached using 
Table 9. The injected fuel mass and energy for all tested fuels in all measured loads.

\begin{tabular}{|c|c|c|c|c|c|c|}
\hline \multirow[t]{2}{*}{ Load } & \multicolumn{2}{|c|}{ D100 } & \multicolumn{2}{|c|}{ R20B10D70 } & \multicolumn{2}{|c|}{ R20B20D60 } \\
\hline & $\overline{\mathrm{mg} \mathrm{cycle}^{-1}}$ & $\mathrm{~kJ} \mathrm{cycle}^{-1}$ & $\overline{\mathrm{mg} \mathrm{cycle}^{-1}}$ & $\mathrm{~kJ}$ cycle $^{-1}$ & $\overline{\mathrm{mg} \text { cycle }}{ }^{-1}$ & $\mathrm{~kJ} \mathrm{cycle}^{-1}$ \\
\hline $20 \%$ & 27.83 & 1.20 & 27.74 & 1.13 & 27.85 & 1.11 \\
\hline $60 \%$ & 43.5 & 1.88 & 44.11 & 1.8 & 46.25 & 1.84 \\
\hline $100 \%$ & 62.3 & 2.69 & 64.72 & 2.64 & 64.98 & 2.59 \\
\hline
\end{tabular}

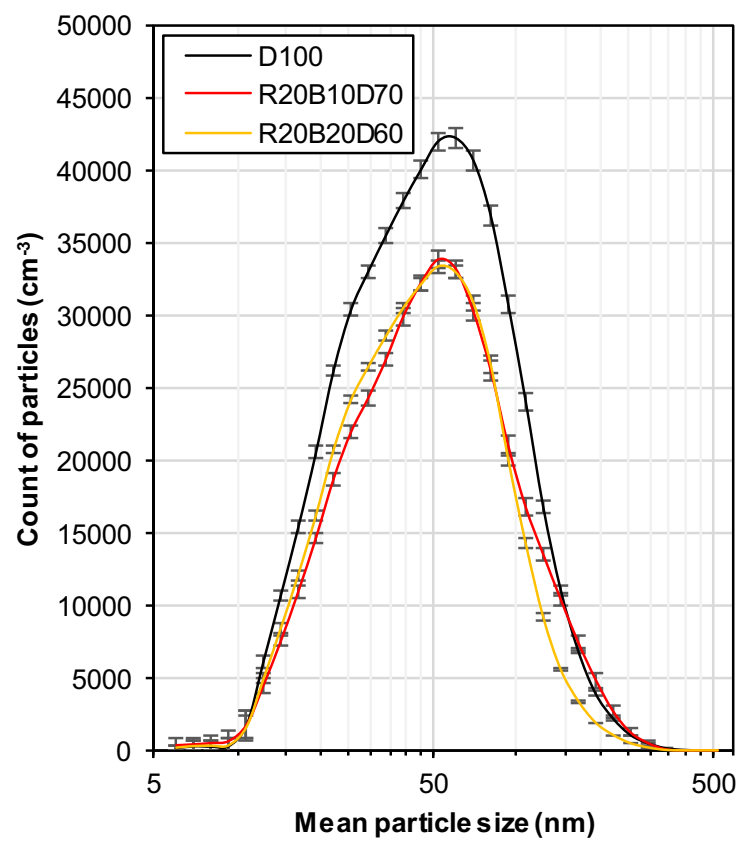

Fig. 18. Result of particle analysis for all tested fuels at $20 \%$ engine load (error bars represent the value of standard deviation).

the blended fuels were lower in comparison with D100 (by $26.61 \%$ with R20B10D70 and by $28.59 \%$ with R20B20D60) as can be seen in Figures 19 and 20, where detailed results of particle analysis for all tested fuels at $60 \%$ engine load in the size of $30-80 \mathrm{~nm}$ are shown. The mean size of the particle with the highest concentration was lower using R20B10D70 in comparison with D100 (D100 - $60.4 \mathrm{~nm}, \mathrm{R} 20 \mathrm{~B} 10 \mathrm{D} 70$ - $52.3 \mathrm{~nm}, \mathrm{R} 20 \mathrm{~B} 20 \mathrm{D} 60-$ $60.4 \mathrm{~nm})$. Also, the peak of concentration of very small particles (approx. $10 \mathrm{~nm}$ ) can be seen for R20B20D60. Similar phenomenon was observed in one of previous study of the authors [51] with vegetable oil-diesel fuel blend. The phenomenon was explained by the worse evaporation ability of vegetable oil during ID and it was connected with premixed combustion. Increased intensity of premixed combustion by $45 \%$ for R20B20D60 fuel at this engine load contributed to very small particles production.

In Figure 21 the result of particle analysis for all tested fuels at $100 \%$ engine load is shown. The decrease of maximum solid particles concentration when using blended fuels was lower at full engine load compared with $20 \%$ and $60 \%$

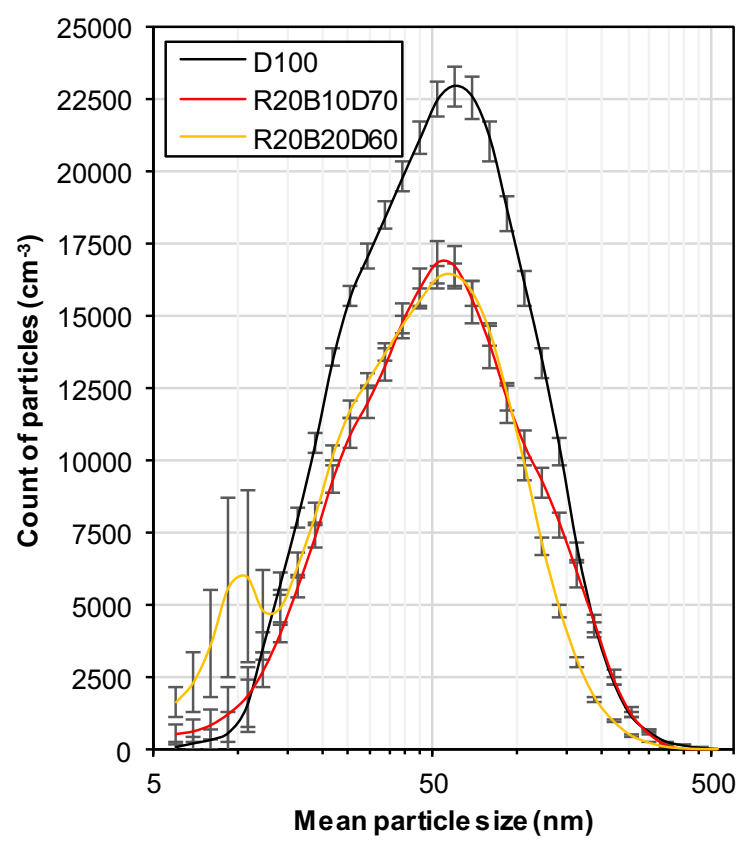

Fig. 19. Result of particle analysis for all tested fuels at $60 \%$ engine load (error bars represent the value of standard deviation).

engine loads (by $14.34 \%$ for R20B10D70 and by $11.49 \%$ R20B20D60). It is evident, that engine under full load produces bigger particles than in previous cases (20\% and $60 \%$ engine load). According to [66] this is caused by higher combustion temperature and higher air-fuel equivalence ratios. Also, similarly to R20B20D60 at $60 \%$ engine load, at this engine load the both of blended fuels tends to create higher count of particles at mean size approx. $10 \mathrm{~nm}$. This can be explained by higher intensity of premixed combustion, which was highest for R20B10D70 at this engine load, and lower volatility of rapeseed oil in the blend.

Figure 22 shows the total concentration of particles for all measured fuels. The noticeable decrease of total count of particles in $1 \mathrm{~cm}^{3}$ between both blended fuels and D100 in all measured cases can be seen. At $20 \%$ engine load the decrease was $23.2 \%$ for R20B10D70 and 25.22 for R20B20D60, at $60 \%$ engine load it was $27.02 \%$ for R20B10D70 and $24.75 \%$ for R20B20D60 and at full engine load it was $16.42 \%$ for R20B10D70 and 16.96 for R20B20D60. It should be taken into account that the total count of the particles is evaluated regardless to the size of 


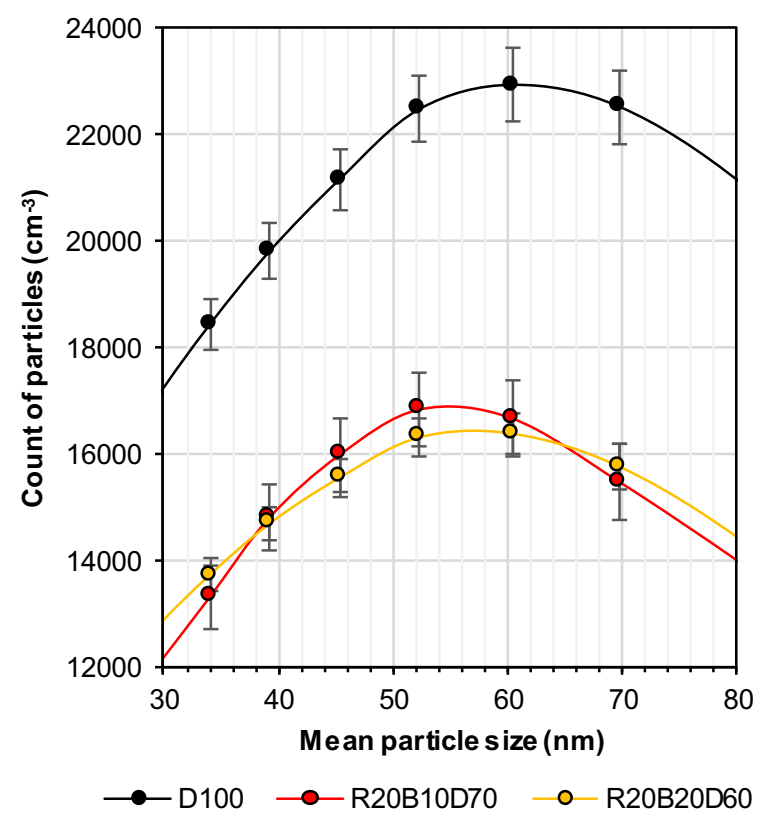

Fig. 20. Detailed results of particle analysis for all tested fuels at $60 \%$ engine load in the size of $30-80 \mathrm{~nm}$ (error bars represent the value of standard deviation).

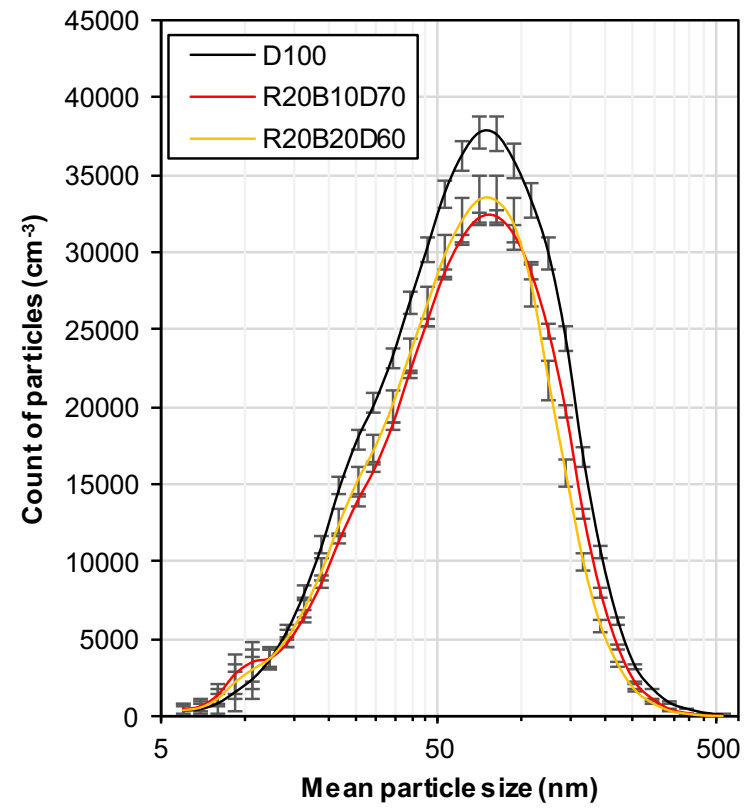

Fig. 21. Result of particle analysis for all tested fuels at $100 \%$ engine load (error bars represent the value of standard deviation).

particles which makes the differences between individual blended fuels less significant. However, using ANalysis Of VAriance (ANOVA), the statistically significant differences were found between all tested fuels at all loads except the difference between R20B10D70 and R20B20D60 at 100\% engine load, where the difference was not significant. ANOVA, complemented with Tukey HSD post-hoc test

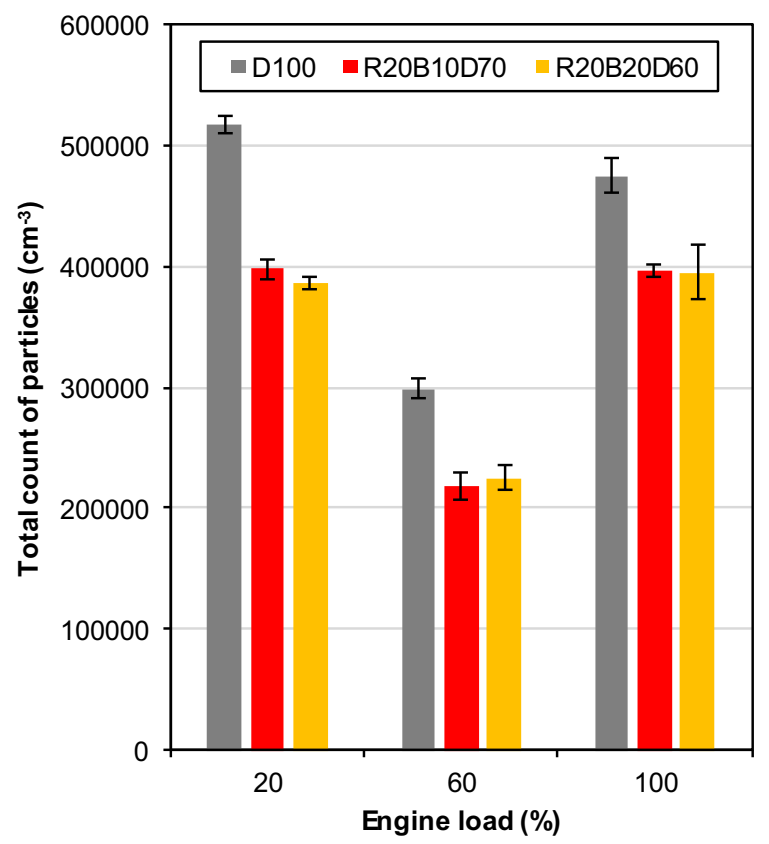

Fig. 22. Total count of particles of all sizes for all tested fuels at all measured loads (error bars represent the value of standard deviation).

Table 10. ANOVA with Tukey HSD post-hoc test for total count of particles at $100 \%$ engine load.

\begin{tabular}{lcccc}
\hline$\alpha=0.05$ & $\begin{array}{c}\text { Sum of } \\
\text { Squares }\end{array}$ & $\begin{array}{c}\text { Degrees } \\
\text { of freedom }\end{array}$ & Variance & $F$-value \\
\hline Between groups & $32.3468 \times 10^{11}$ & 2 & $1.6173 \times 10^{11}$ & 600.796 \\
Within groups & $5.5993 \times 10^{10}$ & 208 & $2.692 \times 10^{8}$ & - \\
Total & $37.9461 \times 10^{11}$ & 210 & - & - \\
\hline
\end{tabular}

Tukey HSD post-hoc test.

D100 vs. R20B10D70: Diff $=-78$ 037.7452, 95\% CI $=-85111.5904$ to $-70963.9000, p=0.0000$.

D100 vs. R20B20D60: Diff $=-80599.9411,95 \% \mathrm{CI}=-86634.9224$ to $-74564.9598, p=0.0000$.

R20B10D70 vs. R20B20D60: Diff $=-2562.1959, \quad 95 \%$ $\mathrm{CI}=-9744.4253$ to $4620.0335, p=0.6774$.

for total count of particles at full engine load can be seen in Table 10.

Concerning total particles count, the reached results are with good agreement with findings of other authors, who found decreased smoke when using vegetable oil-butanoldiesel fuel blends [25, 28, 32], especially with increasing butanol proportion in the fuel blend. Similar trend of smoke was also found for other fuel blends containing butanol [1, 27, 33, 46, 47].

\section{Conclusion}

The article is focused on combustion characteristics, engine efficiency and solid particle production by the turbocharged 
compression ignition engine running on vegetable oil-nbutanol-diesel fuel blends and 100\% diesel fuel. From the reached results the following conclusions were made.

- Lower cylinder pressure was reached during compression and expansion strokes using the blended fuels in comparison with D100 in all cases.

- Combustion temperature was significantly higher in the case of both of blended fuels in comparison with D100.

- Lower peak cylinder pressure and higher cylinder temperature were probably caused by lower mass air flow, mainly affected by the speed of turbocharger and its temperature.

- CD was shorter for both of blended fuels in comparison with D100, while intensity of premixed combustion was increased with increasing proportion of n-butanol in the fuel (by up to $45 \%$ ).

- ID reached using R20B10D70 was shorter in comparison with D100, on the contrary R20B20D60 reached longer ID compared with D100. Shorter ID was caused by higher temperature of charge in the cylinder during ID. Longer ID was caused by low cetane number of the n-butanol and its higher concentration in R20B20D60 fuel blend.

- Both of the blended fuels were found to statistically significantly decrease the production of solid particles in comparison with D100. The decrease for both blended fuels was between $27 \%$ and $16 \%$ compared with D100.

- With increasing proportion of n-butanol, the engine tends to create smaller and thus more dangerous particles.

With increasing pressure on the reduction of GHG and other harmful emissions, such as $\mathrm{NO}_{\mathrm{X}}$ or $\mathrm{PM}$, the research in the field of biofuels is very important in the present time. The production of individual components of harmful emissions is always a trade-off different factors, which may be contradictory. Further experiments will be prepared in order to obtain wider field of view on production harmful emissions when using biofuels and different ambient conditions, e.g. air humidity [67].

From the viewpoint of alternative energy sources for propulsion of vehicles, the electricity is probably going to play the main role. However, in some applications (e.g. propulsion of agriculture machines in the field conditions) it is still very difficult to store sufficient amount of energy at least for one shift. Also, the effectivity of electric drive depends on how the electric energy was produced. Until these issues are resolved the utilization of biofuels seems to be an appropriate alternative for the bridging period. In particular, biofuels that can be used in an unmodified engine have a high potential.

Acknowledgments. This research was funded by Internal Grant Agency of Czech University of Life Sciences Prague, Faculty of Engineering - IGA CULS - 2018:31190/1312/3117, 2019:31190/1312/3101 and 2020:31190/1312/3111.

\section{References}

1 Imtenan S., Masjuki H., Varman M., Rizwanul Fattah I., Sajjad H., Arbab M. (2015) Effect of n-butanol and diethyl ether as oxygenated additives on combustion-emissionperformance characteristics of a multiple cylinder diesel engine fuelled with diesel-jatropha biodiesel blend, Energy Convers. Manag. 94, 84-94. https://doi.org/10.1016/j. enconman.2015.01.047.

2 Heywood J.B. (2018) Internal combustion engine fundamentals, McGraw-Hill, London.

3 European Directive 2015/1513 of the European Parliament and of the Council(2015).

4 Viccaro M., Cozzi M., Rocchi B., Romano S. (2019) Conservation agriculture to promote inland biofuel production in Italy: An economic assessment of rapeseed straight vegetable oil as a self-supply agricultural biofuel, J. Clean. Prod. 217, 153-161. https://doi.org/10.1016/j.jclepro.2019.01.251.

5 Demirbas A. (2003) Biodiesel fuels from vegetable oils via catalytic and non-catalytic supercritical alcohol transesterifications and other methods: A survey, Energy Convers. Manag. 44, 2093-2109. https://doi.org/10.1016/S0196-8904 (02)00234-0.

6 Zahan K.A., Kano M. (2018) Biodiesel production from palm oil, its by-products, and mill effluent: A review, Energies 11, 8, Art. no. 2132. https://doi.org/10.3390/en11082132.

7 Yoon S., Kim M., Kim H., Choi N., Yoon S.K., Kim M.S., Kim H.J., Choi N.J. (2014) Effects of canola oil biodiesel fuel blends on combustion, performance, and emissions reduction in a common rail diesel engine, Energies 7, 12, 8132-8149. https://doi.org/10.3390/en7128132.

8 Mat S.C., Idroas M.Y., Teoh Y.H., Hamid M.F. (2018) Physicochemical, performance, combustion and emission characteristics of melaleuca cajuputi oil-refined palm oil hybrid biofuel blend, Energies 11, 11, Art. no. 3146. https://doi.org/10.3390/en11113146.

9 Klyus O. (2005) Biofuels for self-ignition engines, Sci. J. Marit. Univ. Szczecin (Zesz. Nauk. Akad. Morska w Szczecinie) 7, 153-156.

10 Sonthalia A., Kumar N. (2019) Hydroprocessed vegetable oil as a fuel for transportation sector: A review, J. Energy Inst. 92, 1-17. https://doi.org/10.1016/j.joei.2017.10.008.

11 Laza T., Bereczky Á. (2011) Basic fuel properties of rapeseed oil-higher alcohols blends, Fuel 90, 803-810. https://doi.org/ 10.1016/j.fuel.2010.09.015.

12 Atmanli A., Ileri E., Yuksel B., Yilmaz N. (2015) Extensive analyses of diesel-vegetable oil-n-butanol ternary blends in a diesel engine, Appl. Energy 145, 155-162. https://doi.org/ 10.1016/j.apenergy.2015.01.071.

13 Babu V.M., Murthy M.K., Prasad Rao A.G. (2017) Butanol and pentanol: The promising biofuels for CI engines - A review, Renew. Sustain. Energy Rev. 78, 1068-1088. https://doi.org/10.1016/j.rser.2017.05.038.

14 Geng P., Cao E., Tan Q., Wei L. (2017) Effects of alternative fuels on the combustion characteristics and emission products from diesel engines: A review, Renew. Sustain. Energy Rev. 71, 523-534. https://doi.org/10.1016/j.rser.2016.12.080.

15 Franco Z., Nguyen Q.D. (2011) Flow properties of vegetable oil-diesel fuel blends, Fuel 90, 2, 838-843. https://doi.org/ 10.1016/j.fuel.2010.09.044.

16 Tutak W., Lukács K., Szwaja S., Bereczky Á. (2015) Alcoholdiesel fuel combustion in the compression ignition engine, Fuel 154, 196-206. https://doi.org/10.1016/j.fuel.2015.03.071. 
17 Campos-Fernández J., Arnal J.M., Gómez J., Dorado M.P. (2012) A comparison of performance of higher alcohols/diesel fuel blends in a diesel engine, Appl. Energy 95, 267-275. https://doi.org/10.1016/j.apenergy.2012.02.051.

18 Hönig V., Smrčka L., Ilves R., Küüt A. (2015) Adding biobutanol to diesel fuel and impact on fuel blend parametres, Agron. Res. 13, 5, 1227-1233.

19 Atmanli A., Ileri E., Yüksel B. (2014) Experimental investigation of engine performance and exhaust emissions of a diesel engine fueled with diesel-n-butanol-vegetable oil blends, Energy Convers. Manag. 81, 312-321. https://doi. org/10.1016/j.enconman.2014.02.049.

20 Niculescu R., Clenci A., Iorga-Siman V., Niculescu R., Clenci A., Iorga-Siman V. (2019) Review on the use of diesel-biodiesel-alcohol blends in compression ignition engines, Energies 12, 7, Art. no. 1194. https://doi.org/10.3390/ EN12071194.

21 Yao C., Cheung C.S., Cheng C., Wang Y., Chan T.L., Lee S.C. (2008) Effect of diesel/methanol compound combustion on diesel engine combustion and emissions, Energy Convers. Manag. 49, 6, 1696-1704. https://doi.org/10.1016/j.enconman. 2007.11.007.

22 Atmanli A., Ileri E., Yüksel B. (2015) Effects of higher ratios of n-butanol addition to diesel-vegetable oil blends on performance and exhaust emissions of a diesel engine, $J$. Energy Inst. 88, 3, 209-220. https://doi.org/10.1016/j.joei. 2014.09.008.

23 Rakopoulos D.C., Rakopoulos C.D., Giakoumis E.G., Dimaratos A.M., Kyritsis D.C. (2010) Effects of butanoldiesel fuel blends on the performance and emissions of a high-speed DI diesel engine, Energy Convers. Manag. 51, 1989-1997. https://doi.org/10.1016/j.enconman.2010.02.032.

24 Müller M., Šleger V., Pexa M., Mařík J., Mizera Č. (2015) Evaluation of stability of elastomer packing exposed to influence of various biofuels, Agron. Res. 13, 2, 604-612.

25 Sharon H., Jai Shiva Ram P., Jenis Fernando K., Murali S., Muthusamy R. (2013) Fueling a stationary direct injection diesel engine with diesel-used palm oil-butanol blends - An experimental study, Energy Convers. Manag. 73, 95-105. https://doi.org/10.1016/j.enconman.2013.04.027.

26 Kumar S., Cho J.H., Park J., Moon I. (2013) Advances in diesel-alcohol blends and their effects on the performance and emissions of diesel engines, Renew. Sustain. Energy Rev. 22, 46-72. https://doi.org/10.1016/j.rser.2013.01.017.

27 Rakopoulos D.C., Rakopoulos C.D., Giakoumis E.G. (2015) Impact of properties of vegetable oil, bio-diesel, ethanol and n-butanol on the combustion and emissions of turbocharged HDDI diesel engine operating under steady and transient conditions, Fuel 156, 1-19. https://doi.org/10.1016/ j.fuel.2015.04.021.

28 Mat S.C., Idroas M.Y., Hamid M.F., Zainal Z.A. (2018) Performance and emissions of straight vegetable oils and its blends as a fuel in diesel engine: A review, Renew. Sustain. Energy Rev. 82, 2018, 808-823. https://doi.org/10.1016/j. rser.2017.09.080.

29 Seifollahi M., Amiri H. (2020) Enhanced production of cellulosic butanol by simultaneous co-saccharification and fermentation of water-soluble cellulose oligomers obtained by chemical hydrolysis, Fuel 263, Art. no. 116759. https://doi. org/10.1016/j.fuel.2019.116759.

30 Ndaba B., Chiyanzu I., Marx S. (2015) n-Butanol derived from biochemical and chemical routes: A review, Biotechnol. Rep. 8, 1-9. https://doi.org/10.1016/j.btre.2015.08.001.
31 Pang J., Zheng M., Wang Z., Liu S., Li X., Li X., Wang J., Zhang T. (2020) Catalytic upgrading of ethanol to butanol over a binary catalytic system of $\mathrm{FeNiO}_{\mathrm{x}}$ and $\mathrm{LiOH}$, Chin. J. Catal. 41, 4, 672-678. https://doi.org/10.1016/S1872-2067 (20)63541-0.

32 Lujaji F., Kristóf L., Bereczky A., Mbarawa M. (2011) Experimental investigation of fuel properties, engine performance, combustion and emissions of blends containing croton oil, butanol, and diesel on a CI engine, Fuel 90, 505-510. https://doi.org/10.1016/j.fuel.2010.10.004.

33 Rakopoulos D.C. (2013) Combustion and emissions of cottonseed oil and its bio-diesel in blends with either n-butanol or diethyl ether in HSDI diesel engine, Fuel 105, 603-613. https://doi.org/10.1016/j.fuel.2012.08.023.

34 Rakopoulos C.D., Karellas S., Rakopoulos D.C., Papagiannakis R.G., Giakoumis E.G., Kosmadakis G.M. (2015) Combustion and emissions in an HSDI engine running on diesel or vegetable oil base fuel with n-butanol or diethyl ether as a fuel extender, J. Energy Eng. 142, 2, E4015006. https://doi.org/10.1061/(asce)ey.1943-7897.0000308.

35 Ileri E., Atmanli A., Yilmaz N. (2016) Comparative analyses of n-butanol-rapeseed oil-diesel blend with biodiesel, diesel and biodiesel-diesel fuels in a turbocharged direct injection diesel engine, J. Energy Inst. 89, 4, 586-593. https://doi. org/10.1016/j.joei.2015.06.004.

36 Atmanlı A., Yüksel B., İleri E. (2013) Experimental investigation of the effect of diesel-cotton oil-n-butanol ternary blends on phase stability, engine performance and exhaust emission parameters in a diesel engine, Fuel 109, 503-511. https://doi.org/10.1016/j.fuel.2013.03.012.

37 Doğan O. (2011) The influence of n-butanol/diesel fuel blends utilization on a small diesel engine performance and emissions, Fuel 90, 7, 2467-2472. https://doi.org/10.1016/ j.fuel.2011.02.033.

38 Chen G., Shen Y., Zhang Q., Yao M., Zheng Z., Liu H. (2013) Experimental study on combustion and emission characteristics of a diesel engine fueled with 2,5-dimethylfuran-diesel, n-butanol-diesel and gasoline-diesel blends, Energy 54, 333-342. https://doi.org/10.1016/j.energy.2013.02.069.

39 Altun Ş., Öner C., Yaşar F., Adin H. (2011) Effect of n-butanol blending with a blend of diesel and biodiesel on performance and exhaust emissions of a diesel engine, Ind. Eng. Chem. Res. 50, 15, 9425-9430. https://doi.org/ 10.1021/ie201023f.

40 Atmanli A., Ileri E., Yilmaz N. (2016) Optimization of dieselbutanol-vegetable oil blend ratios based on engine operating parameters, Energy 96, 569-580. https://doi.org/10.1016/j. energy.2015.12.091.

41 Kotek M., Jindra P., Prikner P., Mařík J. (2017) Comparison of PM production in gasoline and diesel engine exhaust gases, Agron. Res. 15, S1, 1041-1049.

42 Mohankumar S., Senthilkumar P. (2017) Particulate matter formation and its control methodologies for diesel engine: A comprehensive review, Renew. Sustain. Energy Rev. 80, 1227-1238. https://doi.org/10.1016/J.RSER.2017.05.133.

43 Dockery D.W., Schwartz J., Spengler J.D. (1992) Air pollution and daily mortality: Associations with particulates and acid aerosols, Environ. Res. 59, 2, 362-373. https://doi. org/10.1016/S0013-9351(05)80042-8.

44 Soleimani M., Amini N., Sadeghian B., Wang D., Fang L. (2018) Heavy metals and their source identification in particulate matter (PM2.5) in Isfahan City, Iran, J. Environ. Sci. 72, 166-175. https://doi.org/10.1016/j.jes.2018.01.002. 
45 Warnatz J., Maas U., Dibble R.W. (2006) Combustion: Physical and chemical fundamentals, modelling and simulation, experiments, pollutant formation, Springer, Berlin, Germany.

46 Siwale L., Kristóf L., Adam T., Bereczky A., Mbarawa M., Penninger A., Kolesnikov A. (2013) Combustion and emission characteristics of n-butanol/diesel fuel blend in a turbocharged compression ignition engine, Fuel 107, 409-418. https://doi.org/10.1016/j.fuel.2012.11.083.

47 Pexa M., Čedík J., Pražan R. (2016) Smoke and $\mathrm{NO}_{\mathrm{X}}$ emissions of combustion engine using biofuels, Agron. Res. 14, 2, 547-555.

48 Jezierska-Thöle A., Rudnicki R., Kluba M. (2016) Development of energy crops cultivation for biomass production in Poland, Renew. Sustain. Energy Rev. 62, 534-545. https://doi.org/10.1016/j.rser.2016.05.024.

49 Čedík J., Pexa M., Peterka B., Holubek M., Mader D., Pražan R. (2018) Effect of biobutanol-sunflower oil-diesel fuel blends on combustion characteristics of compression ignition engine, Acta Technol. Agric. 21, 4, 130-135. https://doi.org/10.2478/ata-2018-0024.

50 Čedík J., Pexa M., Mader D., Pražan R. (2019) Combustion characteristics of compression ignition engine operating on rapeseed oil-diesel fuel blends, Agron. Res. 17, S1, 957-973. https://doi.org/10.15159/AR.19.042.

51 Čedík J., Pexa M., Holůbek M., Mader D., Pražan R. (2018) Effect of sunflower and rapeseed oil on production of solid particles and performance of diesel engine, Agron. Res. 16, S1, 985-996. https://doi.org/10.15159/AR.18.121.

52 ČSN DIN 51900-1. (2014) Testing of solid and liquid fuels Determination of the gross calorific value by the bomb calorimeter and calculation of the net calorific value-Part 1: General information, basic equipment and method, Deutsches Institut für Normung e.V., Berlin.

53 ČSN DIN 51900-2. (2014) Testing of solid and liquid fuels Determination of the gross calorific value by the bomb calorimeter and calculation of the net calorific value - Part 2: Method using isoperibol or static jacket calorimeter, Deutsches Institut für Normung e.V., Berlin.

54 EN 590 (2013) Automotive fuels. Diesel. Requirements and test methods, European Committee for Standardization, Brussels (CEN-CENELEC Control Center: Avenue Marnix 17, B-1000 Brussels).

55 McDonnell K., Ward S., Leahy J.J., McNulty P. (1999) Properties of rapeseed oil for use as a diesel fuel extender, JAOCS - J. Am. Oil Chem. Soc. 76, 5, 539-543. https://doi. org/10.1007/s11746-999-0001-y.

56 Ozsezen A.N., Canakci M., Sayin C. (2008) Effects of biodiesel from used frying palm oil on the performance, injection, and combustion characteristics of an indirect injection diesel engine, Energy Fuels 22, 2, 1297-1305. https://doi.org/10.1021/ef700447z.

57 Ozsezen A.N., Canakci M. (2011) Determination of performance and combustion characteristics of a diesel engine fueled with canola and waste palm oil methyl esters, Energy Convers. Manag. 52, 108-116. https://doi.org/10.1016/ j.enconman.2010.06.049.

58 Gailis M., Rudzitis J., Kreicbergs J., Zalcmanis G. (2017) Experimental analysis of Hydrotreated Vegetable Oil (HVO) and commercial diesel fuel blend characteristics using modified CFR engine, Agron. Res. 15, 4, 1582-1601. https://doi. org/10.15159/AR.17.011.

59 Aldhaidhawi M., Chiriac R., Badescu V. (2017) Ignition delay, combustion and emission characteristics of Diesel engine fueled with rapeseed biodiesel - A literature review, Renew. Sustain. Energy Rev. 73, 178-186. https://doi.org/ 10.1016/j.rser.2017.01.129.

60 Xiao J., Jia M., Chang Y., Li Y., Xu Z., Xu G., Liu H., Wang T. (2017) Numerical optimization and comparative study of n-butanol concentration stratification combustion and n-butanol/diesel reactivity stratification combustion for advanced Compression Ignition (CI) engine, Fuel 213, 83-97. https://doi.org/10.1016/j.fuel.2017.10.104.

61 Devan P.K., Mahalakshmi N.V. (2008) Performance, emission and combustion characteristics of poon oil and its diesel blends in a DI diesel engine, Fuel 88, 861-867. https://doi. org/10.1016/j.fuel.2008.11.005.

62 Koder A., Schwanzer P., Zacherl F., Rabl H.P., Mayer W., Gruber G., Dotzer T. (2018) Combustion and emission characteristics of a $2.2 \mathrm{~L}$ common-rail diesel engine fueled with jatropha oil, soybean oil, and diesel fuel at various EGR-rates, Fuel 228, 23-29. https://doi.org/10.1016/ j.fuel.2018.04.147.

63 Yilmaz N., Vigil F.M., Benalil K., Davis S.M., Calva A. (2014) Effect of biodiesel-butanol fuel blends on emissions and performance characteristics of a diesel engine, Fuel 135, 46-50. https://doi.org/10.1016/j.fuel.2014.06.022.

64 Karabektas M., Hosoz M. (2009) Performance and emission characteristics of a diesel engine using isobutanol-diesel fuel blends, Renew. Energy 34, 6, 1554-1559. https://doi.org/ 10.1016/J.RENENE.2008.11.003.

65 Rakopoulos D.C., Rakopoulos C.D., Hountalas D.T., Kakaras E.C., Giakoumis E.G., Papagiannakis R.G. (2010) Investigation of the performance and emissions of bus engine operating on butanol/diesel fuel blends, Fuel 89, 2781-2790. https://doi.org/10.1016/j.fuel.2010.03.047.

66 Geng L., Chen Y., Chen X., Lee C.F. (2019) Study on combustion characteristics and particulate emissions of a common-rail diesel engine fueled with n-butanol and waste cooking oil blends, J. Energy Inst. 92, 3, 438-449. https://doi.org/10.1016/j.joei.2018.05.004.

67 Chybowski L., Laskowski R., Gawdzińska K. (2015) An overview of systems supplying water into the combustion chamber of diesel engines to decrease the amount of nitrogen oxides in exhaust gas, J. Mar. Sci. Technol. 20, 3, 393-405. https://doi.org/10.1007/s00773-015-0303-8. 